J O UR N A L

OF FESTIVE

STUDIES

\title{
THE POLITICS OF CARNIVAL
}

\section{Venice Carnival from the Middle Ages to the Twenty- First Century: A Political Ritual Turned "Consumer Rite"?}

\section{Gilles Bertrand}

University of Grenoble Alpes, France

\section{KEYWORDS}

Venice

Carnival

republic

masks

social cohesion

civic ritual

commodification

\section{ABSTRACT}

As with other carnivals around the world, the history of the Venetian Carnival sheds light on the complex dialectic between festivity and politics and more particularly on the growing need for political authorities to control the urban environment. This article provides a longue durée approach to carnival in Venice and unpacks the meaning of its successive metamorphoses. During the Middle Ages, Venetians used carnival as a defense strategy for their city, intended to ensure the cohesion of its various neighborhoods around a common destiny. In the fifteenth century, the legacy of public festivals for both rich and poor gave way to a more official celebration, which allowed Venice to outdo its European rivals. The civilized and policed expressions that were elaborated from the Renaissance until the eighteenth century gradually set Venetian Carnival apart from the exuberance and invertibility displayed by rustic carnivals in other parts of Europe. However watered-down and commodified present-day Venetian Carnival may seem, it continues to raise eminently political issues, most of which have to do with the appropriation of public space by private interests and the recreation of traditions for mass consumption. 


\section{$J O U R N A L$}

O F FESTIVE

\section{STUDIES}

1. Giustina Renier Michiel, Origine delle feste veneziane, 5 vols. (Venice: Tipografia di Alvisopoli, 1817).

All translations in the article are

by the author unless otherwise noted.

2. Bianca Tamassia Mazzarotto, Le feste veneziane: I giochi popolari, le cerimonie religiose e di governo (Florence: Sansoni, 1961). Urban Padoan published many books on Venice between 1966 and 1998, each of which focused on a particular aspect of Venetian

festivals and masks. See, for instance, Lina Urban Padoan, Processioni e feste dogali: "Venetia est mundus" (Vicenza: N. Pozza,

1998). Stefania Bertelli, II Carnevale di Venezia nel Settecento (Rome: Jouvence, 1992). Reato's series of illustrated books on the

history of Venetian masks and carnival were published between 1981 and 1998.

3. See Pino Correnti, I/ carnevale di Venezia (Milan: Ecotour, 1968); Maria Teresa Muraro, "La festa a Venezia e le sue manifestazioni rappresentative: Le compagnie della Calza e le Momarie," in Storia della cultura veneta, ed.

Girolamo Arnaldi and Manlio Pastore Stocchi, vol. 3, Dal primo Quattrocento al Concilio di Trento, no. 3 (Vicenza: Neri Pozza, 1981),

315-41; Lina Urban Padoan, "Feste ufficiali e trattenimenti privati," in Storia della cultura veneta, vol. 4, Il Seicento, no. 1 (Vicenza:

Neri Pozza, 1983), 575-600; Lina Urban Padoan, "Il carnevale veneziano," in Storia della cultura veneta, vol. 5, II Settecento, no. 1 (Vicenza: Neri Pozza, 1985), 63146; and Pompeo Molmenti, Storia di Venezia nella vita privata dalle origini alla caduta della Repubblica (1879; Bergamo: Istituto

\section{Venice Carnival from the Middle Ages to the Twenty-First Century: A Political Ritual Turned "Consumer Rite"? \\ Gilles Bertrand}

The political dimension of Venice Carnival has been a focus of academic and independent scholarship since at least the nineteenth century, when the female Venetian aristocrat Giustina Renier Michiel connected local festive dynamics to the commemorative politics of the (then deceased) Republic of Venice in Origine delle feste veneziane, published in 1817. The typology of Venetian festivals laid out by Renier Michiel was refined in the 1960s by specialists in the history of Venetian culture Bianca Tamassia Mazzarotto and Lina Urban Padoan, while in the early 1990s, as a counterpoint to folklorist Danilo Reato's illustrated books, historian Stefania Bertelli published a critical book derived from her master's thesis (tesi di laurea) on the political meaning of Venice Carnival in the eighteenth century. ${ }^{2}$ Other twentieth-century works that commented on the festivity's political dimension (albeit without theorizing it) include Pino Correnti's 1968 synthesis, various contributions to the Storia della cultura veneta books, and several book chapters that relied on historian and politician Pompeo Molmenti's classic history of Venice (1879) for their descriptions of pre-1797 carnival. ${ }^{3}$

Since the 1980s, the best scholarship on the consubstantial links between Venice Carnival and the political sphere has come from English-speaking scholars, including Edward Muir, Peter Burke, and James H. Johnson (see also Samuel Kinser's article in this issue). ${ }_{4}^{4}$ However, these have mostly focused on the medieval and Renaissance periods and have consistently overlooked the contemporary period. To specialists of Venice, in fact, the history of carnival from the nineteenth to the twenty-first-century usually boils down to the following observations: carnival was prohibited by the French and Austrian authorities from 1797 to 1848, experienced a brief resurgence in unified Italy (1867) before evaporating for the remainder of the century, only to come back in 1980 as a commercialized festival deprived of any historical component (its 2020 theme for instance was "Game, Love, and Madness"). 5

While I agree that the recent period is not as conducive to a political history approach as the seventeenth and eighteenth centuries, I do think that the evolution of Venice Carnival should be studied over the long term if we are to grasp the full scope of its political meaning. First there was a medieval carnival, when Venice was still a Comune (township), from the eleventh to the thirteenth centuries; then, under the leadership of the dominant aristocratic group, there was successively a Renaissance carnival and a baroque carnival; later still, there was a carnival of the Venetian "nation" that reappeared in the context of the Austrian domination of the nineteenth century. Let us not forget the twentieth-century carnival of aesthetes and exiled princes either, or the return of carnival in 1980, which is now compressed into about ten days leading up to Lent and has put Venice back in the running for winter capital of the world. Such continual transformations preclude any monolithic description of Venice Carnival, and we clearly need to distance ourselves from the images that the eighteenth century has etched into our minds.

As complex as the history of Venice Carnival is, it does not mean, however, that one should not look for long-term historical structures and overarching themes. Indeed, from its presumed birth in Venice at the end of the eleventh century until the nineteenth century at least, Venetians 


\section{$J O U R N A L$ OF FESTIVE}

\section{STUDIES}

italiano d'arti grafiche, 1927-29).

Many recent works, such as those published by Alessandro Renier between 2007 and 2011, are based on an uncritical acceptance of Molmenti's account.

4. Edward Muir, Civic Ritual in Renaissance Venice (Princeton, $\mathrm{NJ}$ : Princeton University Press, 1981); Peter Burke, "Le carnaval de Venise: Esquisse pour une histoire de longue durée," in Les jeux à la Renaissance, ed. Philippe Ariès and Jean-Claude Margolin (Paris: J. Vrin, 1982), 55-64; and James H. Johnson, Venice Incognito: Masks in the Serene Republic (Berkeley: University of California Press, 2017).

5. Nineteenth-century carnival has recently been the subject of a number of historical reassessments. See Alvise Zorzi, Venezia austriaca (1798-1866) (1985; Gorizia: Libreria ed. Goriziana, 2000); Marco Fincardi, “I fasti della 'tradizione': Le cerimonie della nuova venezianità," in La Storia di Venezia: L'Ottocento e il Novecento, ed. Mario Isnenghi and Stuart J. Woolf (Rome: Istituto della Enciclopedia italiana, 2002), 2:1485-1522; and Giandomenico Romanelli, "Les fêtes du XIXe siècle," in Venise en fêtes, ed. Georges Herscher (Paris: Chêne, 1992), 141-88. Scholarship on twentieth-century carnival, however, remains quasi nonexistent. The only references are and Fiora Gandolfi, "Les fêtes du XXe siècle," in Venise en fêtes, 189-226, and Danilo Reato, Storia del carnevale di Venezia (Venice: Amministrazione della provincia di Venezia, Assessorato alla cultura, 1988); Herscher, ed., Venise en fêtes; Alessandro Renier, Venezia '800: Il Carnevale. Primo '900. La Riva have constantly been concerned with sustaining a self-regulating community. Carnival was but one of the rules that the Venetian community set to itself, not just to punctuate the seasonsas did the popular liturgies studied by ethnologist and folklorist Claude Gaignebet-but also to combat hostile external forces and to build social harmony. ${ }^{6}$ This does not make the history of Venice more linear, since no festive configuration has ever endured through the centuries. But it allows us to explore the many ways carnival may have contributed to the creation of a "Venetian community."

In the fifteenth century, having become one of the key civic rituals celebrating the political and economic successes of La Serenissima (the Most Serene Republic of Venice) for the whole world to see, carnival underwent a major transformation that paralleled the formation of a "Venetian myth" (studied in its successive phases by historians Élisabeth Crouzet-Pavan and Gino Benzoni). ${ }^{7}$ Not until the late sixteenth century did the carnival practices that have become familiar to us become stable. While continuing to contribute to civic cohesion, carnival became increasingly controlled by the aristocracy. Its aesthetics became more and more refined, until, in the eighteenth century, it became the very symbol of urban carnivals, attended by princes and members of the elite from all over Europe, an emblem of the art of conversation and of the dynamics of secrecy stimulated by the "civilizing process" dear to sociologist Norbert Elias. ${ }^{8}$

More than the Renaissance, the Enlightenment is deemed to have been a sort of pinnacle for carnival, until, in 1797, the Republic of Venice ceased to exist. The centuries that followed ceaselessly memorialized the main aspects of this "golden age": courtesans, opera music and chamber concerts, the custom of wearing a mask and a tricorn with a lace shawl called bautta, and the freedom of going incognito. The association of Venetian Carnival with freedom-the freedom to transgress taboos and to be someone else without breaking the laws of the republic-remains strong today, probably because it has been popularized in literature, engravings, paintings, and music since the eighteenth century. Authors from the second half of the nineteenth century like the Goncourt brothers, Hugo von Hofmannstahl, and Arthur Schnitzler have, in particular, modeled our vision of the preceding centuries of carnival. ${ }^{9}$ In the twentieth century, tourist advertising came to replace such media. Ironically, the eighteenth century was far from being an era of unbridled enjoyment, as carnival was then strictly controlled by the authorities. The seventeenth century, rather, and its attendant baroque carnival, is the one that most enduringly marked the history of the Venetian Carnival. That was the time when the state took on the festivities, when theater flourished, when the opera was launched, and when an iconographic system initiated by engraver Giacomo Franco (fig. 1) and extended by painters Joseph Heintz (1600-78) (fig. 2) and Luca Carlevarijs (1663-1730) turned Venice into a major European festive center.

To analyze the changing meaning of Venice Carnival over the longue durée, one needs to escape the narrow theoretical model of a liberating festival, or that of pleasurable transgression, and reinscribe it into a social and political process spanning several centuries. Indeed, the expression "fête à l'envers" (upside-down festival), selected by anthropologist Daniel Fabre in 1992 to synthesize the essence of rural, urban, and court carnivals seems hopelessly inadequate when discussing Venice Carnival. ${ }^{10}$ How can we imagine that everyday life was turned on its head in the "civilized" and "policed" city of Venice when the supposed "inversion" became almost permanent 


\section{$J O U R N A L$ \\ OF FESTIVE}

\section{STUDIES}

degli Schiavoni. I Pubblici Giardini (Venice: La Toletta, 2013); Joseph Rubenstein. "Carnival Unmasked: Transformations of Performance in Venice," Anthropology Humanism Quarterly 15, nos. 2-3 (1990): 53-60; and Charles Arcordia and Chantal Dickinson, "Tourism Field Studies: Experiencing the Carnival of Venice," Journal of Hospitality

\& Tourism Education 25, no. 3 (2013): 146-55.

6. Claude Gaignebet, Le Carnaval: Essais de mythologie populaire (Paris: Payot, 1974) (text established by Marie-Claude Fromentin).

7. Élisabeth Crouzet-Pavan, Venise triomphante: Les horizons d'un mythe (Paris: Albin Michel, 1999) (translated by Lydia G. Cochrane as Venice Triumphant: The Horizons of a Myth [Baltimore, MD: Johns Hopkins University Press, 2002]); Gino Benzoni, "Venezia, ossia il mito modulato," in Crisi e rinnovamenti nell'autunno del

Rinascimento a Venezia, ed. Vittore Branca and Carlo Ossola (Florence: Olschki, 1991), 43-59; and Gino Benzoni, ed., Le metamorfosi di Venezia: Da capitale di stato a città del mondo (Florence:

Olschki, 2001).

8. Norbert Elias, The Civilizing Process (New York: Urizen Books,

9. Edmond and Jules de Goncourt, L'Italie d'hier, notes de voyage, 1855-1856 (Paris: G. Charpentier and E. Fasquelle, 1894); Hugo von Hofmannstahl, Andreas or the United (London: J.

M. Dent \& Sons, 1936) (Andreas oder die Vereinigten was an unfinished novel, written between 1907 and 1927, and finally published

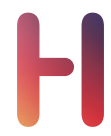

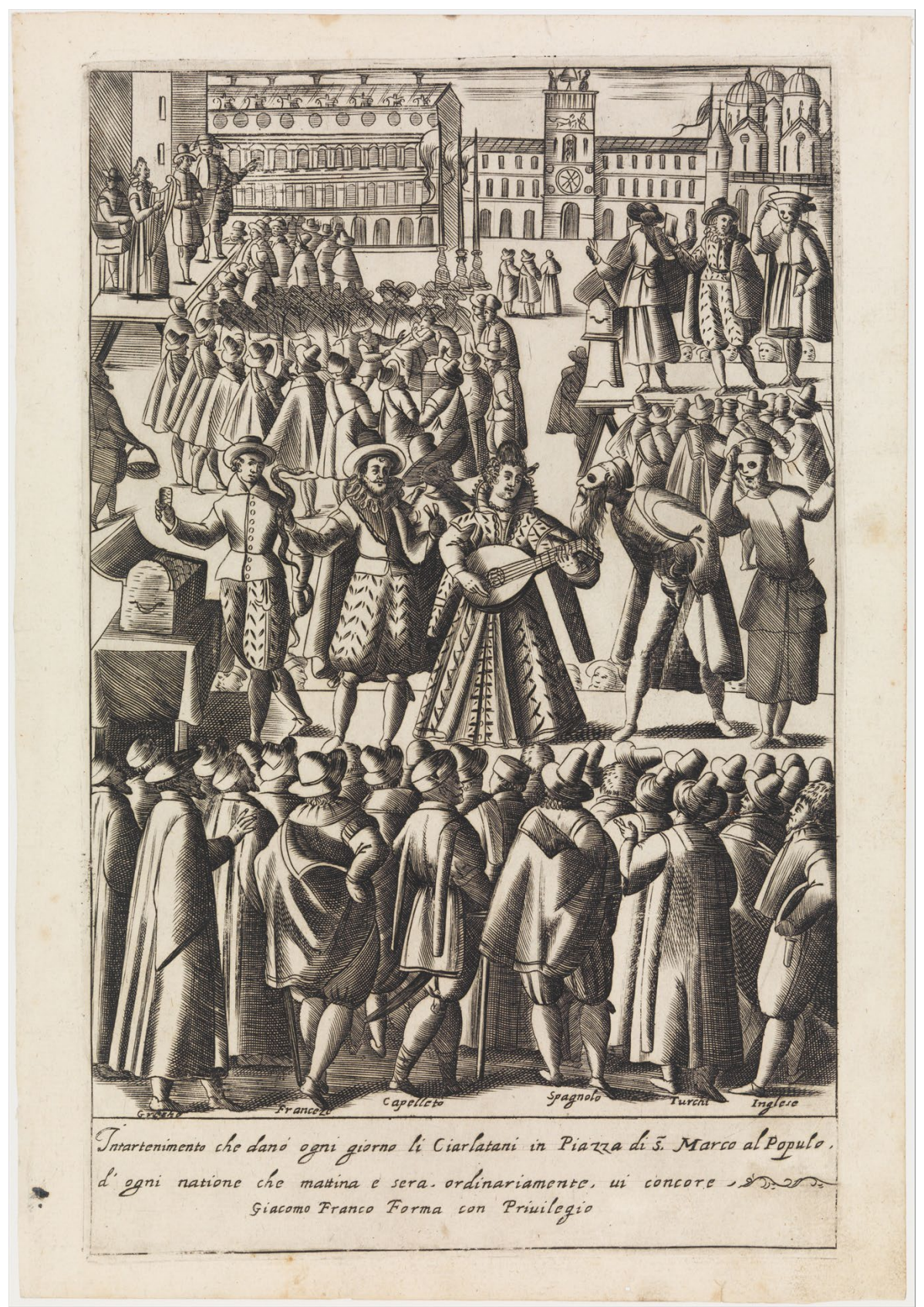

Figure 1. Giacomo Franco (1550-1620), Ciarlatani in Piazza S. Marco (Charlatans in Piazza S. Marco), from his Habiti d'huomeni et donne Venetiane, circa 1610. Engraving. Metropolitan Museum of Art, New York.

in the modern era (from the sixteenth to the eighteenth centuries) and when carnival practices largely exceeded the traditional ten-day pre-Lenten period to spread through the famous "halfyear" described in the age of Enlightenment? Far from being an exception, a "time out of time," carnival on the lagoon was clearly more like the rule, inspiring a new nickname for Venice: the "Republic of the Masks."11

With these preliminary remarks in mind, I now offer a broad synthesis of the politics of Venice Carnival from the medieval to the contemporary period, centering on four "moments" and ending on a reflection on twenty-first-century carnival as a rite of both consumption and commemoration. 


\section{J O U R N A L}

\section{OF FESTIVE}

\section{STUDIES}

in German in 1932); and Arthur Schnitzler, Casanova's Homecoming (New York: Priv. print for subscribers only, 1921) (first published in German as Casanovas Heimfahrt in 1918).

10. Daniel Fabre, Carnaval ou la Fête à l'envers (Paris: Gallimard,

1992).

11. Alessandro Fontana, // vizio occulto (Ancona: Transeuropa, 1989). See also, Alessandro Fontana, "La vérité des masques," in Venise 1297-1797: La république des castors, ed. Alessandro Fontana and Georges Saro (Saint-

Cloud: ENS Editions Fontenay/

Saint-Cloud, 1997), 235-61.

12. Burke, "Le carnaval de Venise." 13. Ibid., 57.

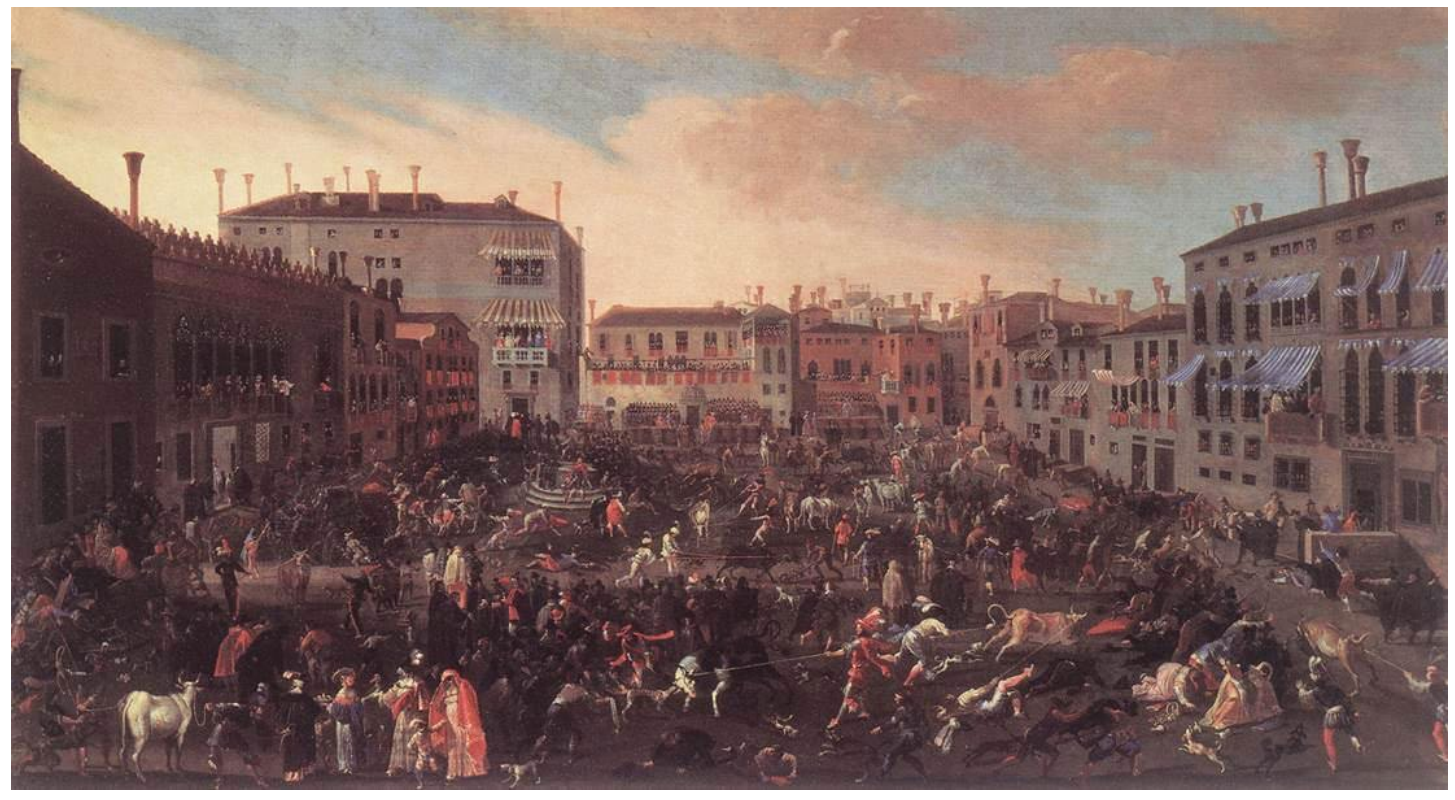

Figure 2. Giuseppe Heintz II (circa 1600-78), The Bull Hunt in Campo San Polo, 1648. Oil on canvas. Museo Correr, Venice.

\section{An Instrument of Civic Defense Serving the Venetian Community (Thirteenth-Fifteenth Centuries)}

As historian Peter Burke surmised in his 1982 essay, the physiognomy of twelfth-century Venetian Carnival was probably similar to that of other Mediterranean carnivals. ${ }^{12}$ In Venice as much as in Florence, Barcelona, Seville, Rome, Naples, and Montpellier, medieval carnival was characterized by "the freedom to eat and drink gargantuan amounts, to wear a mask, to insult your neighbors, to pelt them with eggs, lemons, oranges, etc., and to sing songs full of political or sexual innuendos. ${ }^{\prime 13}$ As early as the twelfth century, however, these conventional pre-Lenten expressions of gluttony and concupiscence combined with a commemoration of the milestones of local history, gradually turning carnival into a site of civic liturgy. Such a political appropriation explains why the festivities barely maintained themselves after the fall of the Republic of Venice in 1797.

In the absence of images and with only few written testimonies to rely on, delineating presixteenth-century carnival is no small task. While the Comune Veneciarum, the people's assembly, lasted beyond the thirteenth century, its role kept decreasing as the oldest and richest families consolidated their own assemblies of "wise men": the Great Council or "Major Council," which stopped recruiting new members between 1297 and 1314, and the "Council of Ten," which became permanent after 1335. Based on the documents traditionally cited by scholars since Molmenti (1819-94)-starting from Doge Vitale Falier's 1094 edict granting the right to celebrate carnival in the run-up to Lent (carnis laxatio) - as well as on a few accounts handed down about carnival, the veracity of which cannot be established with certainty, it would seem that violence was a constant feature of carnival before and after the thirteenth century. A ban on egg throwing was thus issued in 1268 , while a February 12,1339 , law denounced past misdemeanors committed by maskers. More significantly, a 1458 law forbade men from masking as women to enter female monasteries. Cruelty toward animals also seems to have been a feature of medieval 


\section{$J O U R N A L$ \\ OF FESTIVE}

\section{STUDIES}

14. Giovanni Rossi, Costumi Veneziani, unpublished manuscript, vol. 12, Cod. Marc. It. VII 1397 (9288), folios 67-69, Biblioteca Marciana, Venice; and Michele Battagia, Cicalata sulle Cacce dei Tori Veneziane (Venice: Tip.

G. B. Merlo, 1844) (text was initially drafted in 1834).

15. This particular ritual took place at Campo San Luca, between St. Mark's Square and the Grand Canal.

16. Molmenti, Storia di Venezia, vol. 1, La grandezza. carnival. It actually shocked chroniclers until the early nineteenth century. In the 1830 s and 1840s, for instance, such scholars as Giovanni Rossi and Michele Battagia remembered with horror the tortures inflicted on defenseless oxen during the bull hunts (caccia al toro), when the hounds weakened the animals by biting their ears, thereby simplifying the sportsman's task. ${ }^{14}$ It would appear that geese and cats were not spared either.

Such violence, however, hardly aimed at overthrowing the social order: it was rooted in the tradition of military self-defense and sporting exercise that characterized male sociability in the city's various neighborhoods. This is probably why it was allowed to continue well into the eighteenth century. The stick fights-and later fist fights (lotte dei pugni)-that pitted two factions of the people, the Castellani and the Nicolotti, geographically located on either side of the Grand Canal (fig. 3), took place every year on the Ponte dei Pugni (Bridge of Fists) in San Barnaba, near Campo Santa Margherita, until 1705, when they were branded as "brawls" and suppressed.

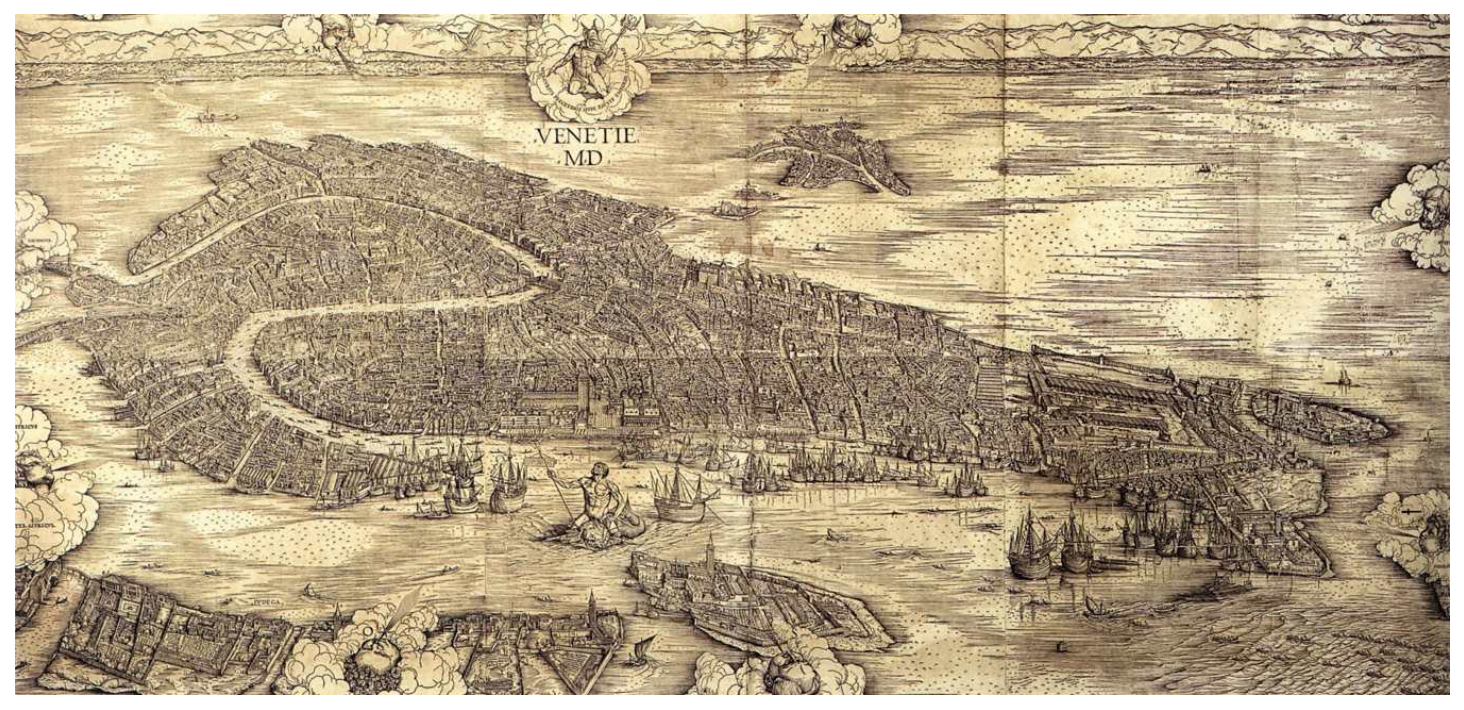

Figure 3: Jacopo de’ Barbari, Venice map, 1500. Woodblock printing. Museo Correr, Venice.

Despite the threat they posed to public safety, bull hunts were permitted from the first day of carnival, December 26, to the last Sunday of the season until 1802, when a platform collapsed due to an angered animal at Campo Santo Stefano, not far from the Academy Bridge, crushing a group of spectators. The Fat Thursday "Hercules's Strength" show, an acrobatic spectacle of men perched on the shoulders of other men in such a way as to form human pyramids, was only abolished six years after a tragic rumpus between the Nicolotti and the Castellani took place on May 31, 1810, killing a dozen people (fig. 4). Another violent ritual continued for a long time, namely, the mid-Lent grotesque buffoonery of "the Old Wife" (della Vecchia), during which respects were paid to a puppet old woman whose face was masked, before the people threw themselves on her, cut her belly in two, and, finally, burned her. ${ }^{15}$

Although no historian can accurately date the invention of carnival rituals in Venice, most have stressed the role these rituals have played in La Serenissima's festival system since the fourteenth century. Molmenti, for instance, argued in 1879 that their perpetuation was better explained by their patriotic dimension than by the character of Venice residents, the theatrical shape of the city, or the mildness of the climate conducive to alfresco living. ${ }^{16} \mathrm{He}$ added that the 


\section{$J O U R N A L$ \\ OF FESTIVE}

\section{STUDIES}

17. Muir, Civic Ritual in Renaissance Venice; and Richard. C. Trexler, Public Life in Renaissance Florence (Ithaca, NY: Cornell University Press, 1991).

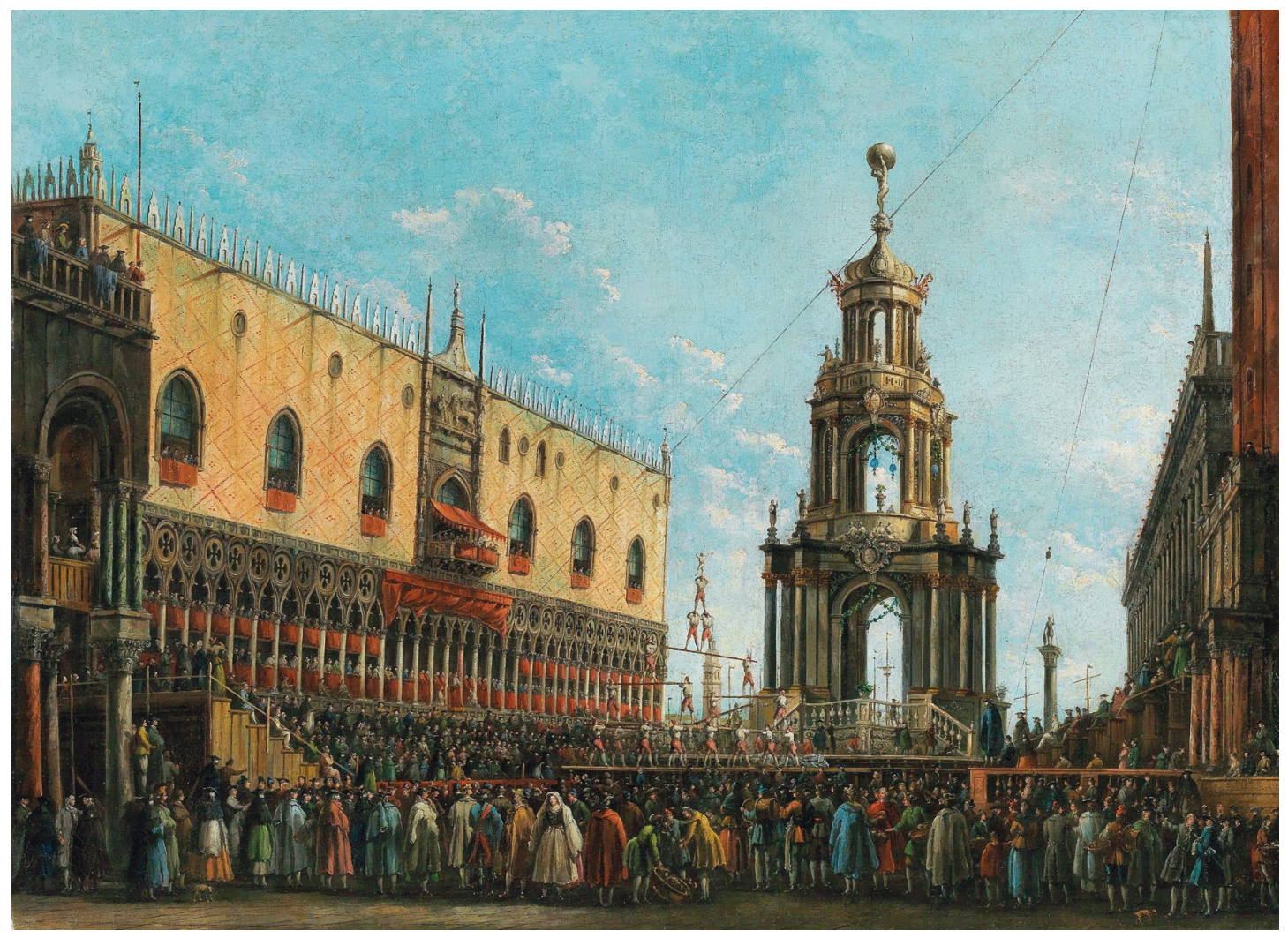

Figure 4. Giuseppe Bernardino Bison (1762-1844), The "Giovedi Grasso" Festival before the Ducal Palace in Venice, circa 1844. Oil on canvas. Private collection.

unification of Italy had especially contributed to the development of a patriotic culture, which Venice intended to dominate in a way appropriate to its former position. A century later, American historian and anthropologist Edward Muir, whose 1981 study of civic rituals in Venice preceded historian Richard C. Trexler's on Florence by a few years, claimed that the ritualization of society and of politics in sixteenth-century Venice had largely contributed to strengthening the city's republican constitution, which earned Venice a reputation for stability in Renaissance Europe.. ${ }^{17}$ Like Molmenti and Muir, I believe that the Venetian festival system, made up of carnival, lavish spectacles, parades, and doge coronations, made a major contribution to the city's identity. I also believe that these civic rituals, whose form stabilized in the Renaissance, have had two main functions: first, to reinforce the well-defined roles of all citizens, thus raising Venetians' awareness of themselves as a community that would look after its members; and second, to raise the city's profile all over Europe by projecting its identity beyond its borders. Unlike Muir and Molmenti, however, I think such a dual use of festivals-for internal and external use-dates back to the medieval period.

Venetian Carnival took on a political significance as early as the twelfth century, since it not only constituted a moment of liberation on the eve of Lent but also became an opportunity to reinforce civic cohesion between all Venetians-nobles, citizens (cittadini) and commoners (popolani)-year-round. A carnivalesque spirit permeated, for instance, the feasting and revelry organized by the historical subdivisions (contrade) of Venice during the Festival of the Twelve Marys, attested from February 2, 1143, when Candlemas became the Feast of the Purification of the Virgin Mary. This festival originally took the form of a waterborne procession of twelve richly 


\section{J O U R N L L \\ OF FESTIVE \\ STUDIES}

18. On this resurrection of the Festa delle Marie in 1930s Venice, see Kate Ferris, Everyday Life in Fascist Venice, 1929-40 (London: Palgrave Macmillan, 2012), 90-99. adorned wooden effigies of the Virgin Mary from Venice to Santa Maria Formosa. It was meant to commemorate Venice's reprisals against Triestine pirates who, sometime in the tenth century (perhaps in 973), had supposedly abducted twelve poor girls whom the doge had dowered before they could be blessed at the Cathedral of San Pietro di Castello with their jewelry. From the twelfth century to its disappearance in 1379, the festival grew from one to three days (January 31 to February 2) and gradually incorporated land processions and banquets that foregrounded women and strengthened the relations between neighborhoods. Rooted in the seventy historical subdivisions of Venice, which organized the boat procession in turn, it came to be seen as such a symbol of social harmony that the fascist regime reinstated it in 1934 as a gondola pageant carrying twelve smiling young brides and their bridegrooms from the Dopolavoro headquarters at the Palazzo della Pescheria to the church of San Pietro. ${ }^{18}$

Interestingly, the Festival of the Twelve Marys was replaced toward the end of the fourteenth century by a new ritual, that of Fat Thursday. This feast, which followed the yearly variations of Lent and Easter, gradually became the main unifying moment of the year. Like its predecessor, it was invented with a view to strengthening social concord by commemorating victory over a common enemy. The event that it memorialized was, this time, the supposed defeat in 1162 of the patriarch of Aquileia and his twelve canons by Doge Vitale II Michiel, who had come to the aid of the patriarch of Grado. More specifically, it commemorated the former's obligation to pay an annual tribute of twelve pigs, symbolizing the twelve canons, and twelve large loaves (to which a bull was added as of 1312) in exchange for the patriarch's freedom. The pigs were tried by a court in the Ducal Palace, in a hall where small wooden castles with crenelated towers were erected to represent the castles of Friuli over which the Aquileia patriarch's temporal power had extended. In execution of the sentence, the pigs were then thrown on the Piazzetta adjoining the basilica where blacksmiths and butchers cut their throats and cut them up. Their meat was distributed to the senators and the bread to the prisoners. The doge and some of the senators later came back to the palace to demolish the wooden castles. Dating from the days of the commune, the ritual lasted until 1797 and emphasized the patriotic and warlike component of carnival's mythical development. The spectacles that were given on that day, including the Hercules's Strength shows, served to manifest and foster urban solidarities, while also celebrating the supremacy of Venice over its neighbors. The latter dimension of the Fat Thursday rituals hints at the second function of the medieval carnivalesque festivals in Venice, which was to stage the city's dynamism for the rest of the world to see.

Another mask-wearing period or "second carnival" thus took place in May or June, during the two-week Ascension Fair attended by the pilgrims on their way to Jerusalem. The festival of La Sensa appears to have initially served to commemorate Doge Pietro II Orsoleo's victorious expedition to Dalmatia in 1000, which would suggest that it celebrated Venice's domination over the Adriatic. In the thirteenth century, its climax became the Marriage to the Sea ceremony, during which the doge was wedded to the ocean to mark the supposed "donation of 1177," whereby the pope, as a gesture of thanks to the Venetians for their assistance in a conflict against Emperor Frederick Barbarossa, conferred on the doge the symbols of his power, thus recognizing the city's jurisdictional autonomy of Venice. Attested by mid-thirteenth-century documents mentioning the building of the first "bucentaur" (master vessel) circa 1253-75, it remained unchanged from the early sixteenth century to the end of the republic in 1797 , by which 


\section{$J O U R N A L$ \\ OF FESTIVE \\ STUDIES}

19. To be fair, carnival jousting and tournaments had already been held on St. Mark's Square from the thirteenth century to the end of the fifteenth century to celebrate the great victories or the memorable episodes of the life of the doge. And it was only in 1647 that the favorite place for nobles to walk under the eyes of onlookers, called the Liston, was moved from Campo Santo Stefano to Piazza San Marco.

20. On this notion of world economy and its evolution in early modern times, see Fernand Braudel, Civilisation matérielle, économie et capitalisme: XVe-XVIIle siècle (Paris: Armand Colin, 1967),

20. Translated by Siân Reynolds as Civilization and Capitalism, 15th-18th Century (New York: Harper \& Row, 1982-84).

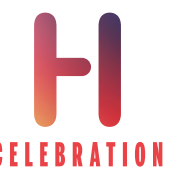

time it had become the favorite moment for foreigners to visit the city. The doge, as captain of Venice, embarked on his state barge, surrounded by a myriad of gondolas loaded with maskers. His trip took him from the historic center of the city, where Saint Mark supposedly repelled the demons, to its outskirts at San Nicolò del Lido, where the doge threw a gold ring into the sea to ward off enemies.

Fat Thursday and the festival of La Sensa both illustrate the desire of Venetians to assert, through carnivalesque entertainment, their supremacy over the Adriatic as well as their prosperity. Freed from the control of the Holy Roman Empire and the Byzantine Empire in 1177, the Venetian Republic held a preeminent position thanks to its trading activities. But the government was careful to mix the more overtly political rituals with popular festivities in order to unite the residents around the celebration of the city's power. It encouraged the competition between the Castellani and the Nicolotti, whose festive exploits took the dual form of military training exercises and demonstrations of strength and skill, such as the Hercules's Strength human pyramid contests on the Piazzetta, which continued beyond the fall of the republic.

The trauma of the War of Chioggia (1379-81), however, during which Venice was besieged by Genoese ships for almost a year before its control of the Adriatic was restored, precipitated the transformation of the Comune, with its contrade, into a Signoria, dominated by aristocrats who were wary of popular influence and sought to channel it. This transformation took place over the course of the fourteenth and fifteenth centuries, while Venetian trade was enjoying its greatest expansion and the republic was beginning to assert its domination on terra firma. It had a huge influence on the city's festival system in general and on the management of carnival in particular. The spatial model of the Festival of the Twelve Marys, rooted in the contrade, was replaced with a new geography centering around the liturgical and political center of St. Mark's Square. As a consequence, the Piazza San Marco also became the focal point of the Fat Thursday celebrations. ${ }^{19}$ Following the annexation of Friuli in 1420, the annual tribute of loaves and pigs was performed by the Venetian government and no longer symbolically by the patriarch of Aquileia as had been the case since 1222. Due to the consolidation of oligarchic institutions, carnival took on the form of a peaceful collective amusement that was increasingly closely controlled by the ruling classes.

\section{A Focal Point in the Competition between European Capitals (Sixteenth-Seventeenth Centuries)}

In the sixteenth and seventeenth centuries, after the Ottoman Empire and Spain gained the upper hand in the Mediterranean and the United Provinces became the center of gravity of the "world economy" (as defined by Fernand Braudel), Venice tried to offset its loss of influence and remain an attractive capital by promoting a carnival whose unrivalled resplendence and luxury became world famous. ${ }^{20}$ From the mid-fifteenth century to 1564 , the young noblemen who were members of the Compagnie della Calza had organized momarie (mimed and danced theatrical performances) and waterborne processions to welcome illustrious guests, as well as private balls, serenades, regattas, naumachiae, land processions, refreshments, and fireworks. After 1560, the Venetian state took over from them by offering Venetians and foreigners, such as Grand Duke Ferdinand II of Tuscany in 1628, an endless succession of regattas, "theaters of the world" on floating pontoons, masses, concerts, and bull hunts that lasted until the fall of 


\section{$J O U R N A L$ \\ OF FESTIVE \\ STUDIES}

21. The capture of Constantinople (capital city of the Byzantine Empire) by the Ottoman army in 1453 was probably the reason behind the emergence of the moresca dance tradition, which would long pit Christians against Moors or Turks. For more details, see Lina Urban Padoan, La festa del giovedi grasso (Venice: Centro internazionale della grafica, 1988); John Forrest, The History of Morris Dancing, 1458-1750 (Toronto: University of Toronto Press, 1999); and Ralph P. Locke, Music and the Exotic from the Renaissance to Mozart (Cambridge: Cambridge University Press, 2015).

22. I wish to thank Mario Infelise for drawing my attention to the literary activities of this "Academy,"

to Heintz's painting, and to the motif of the cloister parlor, whose earliest formulation can be found in an opuscule titled II parlatorio delle monache, published in 1650 by Stamperia di Pasquino.

23. Francesco Bertelli, /l Carnevale Italiano Mascherato ove si Veggono in Figura Varie Inventione di Capritii (Venice: n.p., 1642). the republic. The state also reformed the feast of Fat Thursday, central to carnival celebrations, by "civilizing" it. From 1520 on, pigs no longer entered the Ducal Palace, and, in 1525, their public execution was replaced by that of oxen, officially called "bulls." At the same time, the Council of Ten abolished the legal and military parody commemorating the victory of the doge over the patriarch of Aquileia in 1162 and the conquest of Friuli in 1420. After 1550, the Fat Thursday festivities ceased to be a moment of physical exhibition by the patrician elite and became a public spectacle offered by the republic to the city and to a foreign audience. This signaled the beginning of a new era, that of "baroque carnival," thanks to which the eyes of Europeans continued to focus on Venice, and the nobility, by controlling the festivities, was able to delude itself with the illusion that it was still holding the reins of power.

Though increasingly channeled by aristocratic authorities, popular joy did not entirely disappear from baroque festivals. For three centuries, the more spontaneous entertainments of the "popular" carnival continued to deploy themselves, adding an exuberant, sometimes, improper, cruel, and illicit dimension to the celebration of the carnival desired by the state. Sports and recreational exercises for the people actually grew more prominent during carnival time in the sixteenth and seventeenth centuries. In addition to the bull's execution in front of the Ducal Palace and to the Hercules's Strength human pyramids, Fat Thursday was enriched with a fireworks display, a moresca (a dance miming the struggle between Christians and Moors or Turks), and a new show called "Flight of the Angel," created by a Turkish tightrope walker in 1558, until an accident that occurred in 1759 led to the acrobat being replaced with a dove. ${ }^{21}$ Scores of maskers joined the crowds, drawing inspiration from medieval disguises such as those of the wild man, the old woman, the devil, and animals, from the commedia dell'arte repertoire or from oriental exoticism. The stages set up on trestles by players, charlatans, and animal tamers turned the carnival into a theatrum mundi, a microcosm of the world. Banquets (festini), balls, and gambling in the private gaming rooms (ridotti) or at the public Ridotto di San Moisè, located halfway between St. Mark's Square and Campo Santo Stefano, combined with licentious practices in the small private casinos, gambling dens, bars, cafés, and barber shops.

This baroque carnival dictated rules and practices, going so far as to limit the deployment of sartorial luxury through enforcement of sumptuary laws dating from the sixteenth century. This was the context in which a masking culture developed among the elite. From the 1630s to the 1660s, a leading freethinking or "libertine" learned society named the Accademia degli Incogniti (1630-62) placed the mask at the heart of its activities. Under the leadership of Gian Francesco Loredan, it adopted the motto "Ex ignoto notus" (Known from the Unknown), promoted the use of anagrams in texts, and advocated concealment for women and certain aristocrats attending its sessions. Via the mask, freethinking (or "libertinage" of the mind) evolved into "libertinage" of manners and morals. The Accademia thus participated in the dissemination of certain iconographic motifs, such as the masked visit to the cloister parlor, immortalized by a painting by Joseph Heintz circa 1650 and taken up successfully a century later by painters Pietro Longhi and Francesco Guardi. ${ }^{22}$ During the same period, Heintz placed masks that were the forerunners of the bautta in his scenes of bull hunts on St. Mark's Square, while the printer-bookseller Francesco Bertelli collected engravings of the Carnival of Venice that were to spread throughout Europe (fig. 5) and opera made a striking entrance in Venice with the performance of Andromeda in 1637 at San Cassiano's Teatro Nuovo. ${ }^{23}$ 
J O U R A L

\section{OF FESTIVE}

\section{STUDIES}

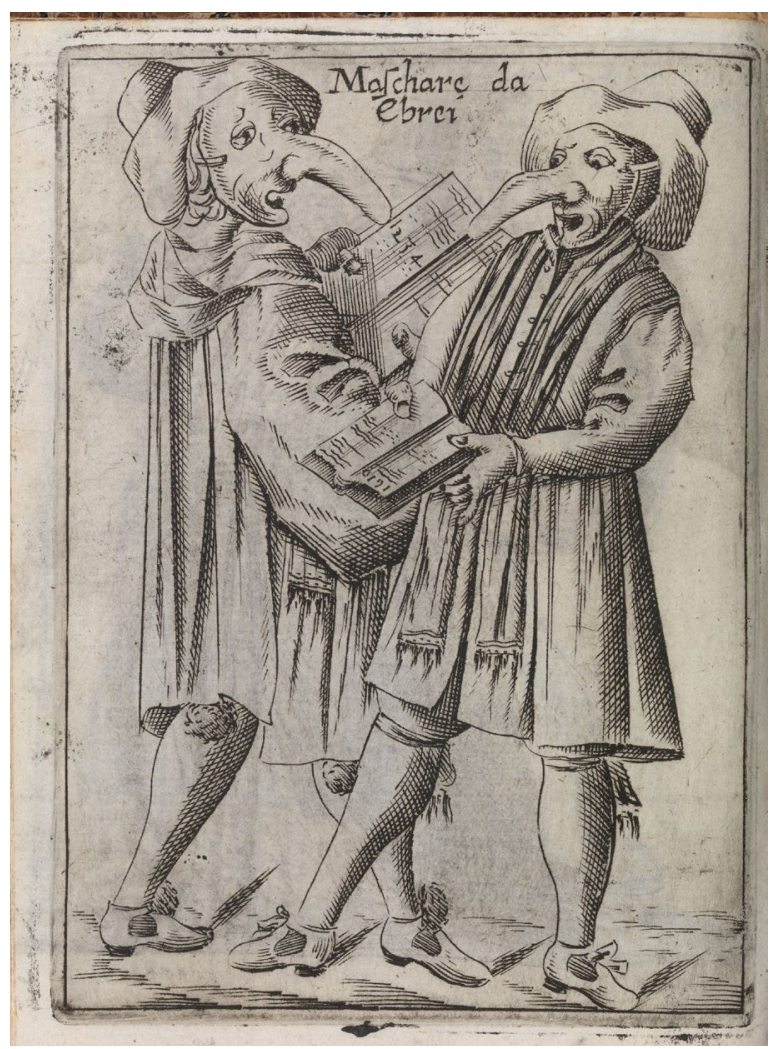

Figure 5. Francesco Bertelli (late sixteenth century-circa 1656), Maschare da ebrei (Masks of the Jews), from his II Carnevale Italiano Mascherato Oue si Veggono in Figura Varie Inuentione di capritii Fra(nces)co Bert[ell]i, 1642. Engraved plate. Metropolitan Museum of Art, New York.

All of this seems to indicate that Venice's long-standing passion for both profane or sacred spectacles, for masking among the elites, and for assumed identities in general was forged at that time, in other words, several decades before painter Luca Carlevarijs depicted the first truly stabilized bautta masks in his vedute (cityscapes) (fig. 6).

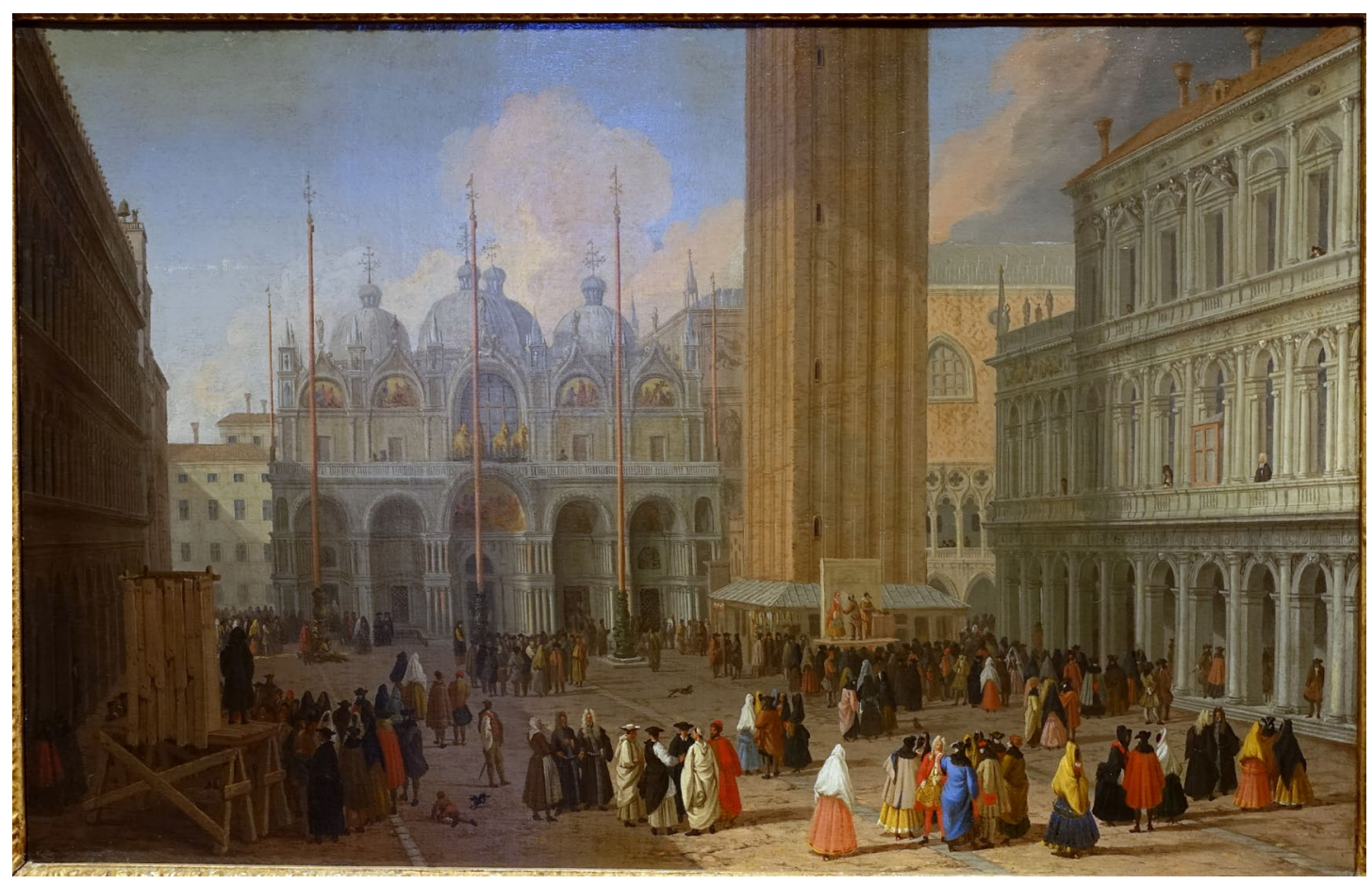

Figure 6. Luca Carlevarijs (1663-1730), St. Mark's Square on the Side of the Basilica of St. Mark's, 1725. The most frequent attribution is to Carlevarijs, but the Sarasota museum site attributes it to his disciple Johan Richter (1665-1745), dating it to around 1720. Oil on canvas. John and Mable Ringling Museum of Art, Sarasota. 


\section{$J O U R N A L$ \\ OF FESTIVE \\ STUDIES}

24. On the taste of Venetians and foreigners for musical shows during Lent, as indicating that a culture of pleasure was diluted throughout the year, see Caroline Giron-Panel, Musique et musiciennes à Venise: Histoire sociale des ospedali (Rome: École française de Rome, 2014), 203-6.

25. In 1686 the Duke of Brunswick-Lünebourg thus organized festivities for his own benefit on his way to the front in the war against the Turks.

26. See Gilles Bertrand, Histoire du Carnaval de Venise, XIe-XXle siècle (Paris: Pygmalion, 2013).
The taste for the spectacular, which led to the dominance of opera in the seventeenth century and of theater in the eighteenth, largely contributed to the prestige of carnival. But Lent itself was not excluded from the world of enjoyment and pleasure. Though theaters were then closed, performances by choir girls in churches sometimes resembled those of vocalists in upper-class entertainment venues. By spilling out of carnival time, the carnivalesque spirit thus connected profane festive time and the religious time of Lent or Advent. As has been noted by historian Caroline Giron-Panel, it unified the whole calendric year in Venice. ${ }^{24}$ The prestige associated with the office of governor of conservatories in the race for honors among the nobility testifies to the logic of pleasure that dominated Venetian society year-round.

In the seventeenth century, carnival came to merge with another type of festivity, that given in honor of foreign dignitaries (or which foreign princes gave to themselves during their visit). ${ }^{25}$ Venetian Carnival was thus transformed into a major site of cultural competition between European capitals. Numerous German princes went there to show their rank, before importing the carnival to Munich, or even Hanover. Louis XIV's fascination for Venice was equivocal: on the one hand, he tried to wrestle from La Serenissima the primacy that it had among European sovereigns as an ideal setting for their manifestations of pomp and splendor; on the other, he drew inspiration from Venice and its festivals by encouraging the construction of a grand canal at Versailles and by underwriting a series of "Venetian" comic operas and ballets, with music by the likes of André Campra, between 1697 and 1710.

\section{A Controlled Festival That Civilized and Policed Manners While Also Allowing Steam to Be Let Off (Eighteenth Century)}

In the Age of Enlightenment, carnival displayed yet another face, symbolized by the bautta mask. With the incognito, a new carnival emerged that shaped politics for internal use, controlled behaviors, and civilized and policed manners and morals, while also allowing the people-albeit less and less-a few opportunities for letting off steam. This controlled carnival fit into the ceremonial of the republic, with its strict rules and its control over people's movements. Far from equalizing social conditions, it appeared to be the exact opposite of a time of spontaneous or unbridled overturning of social hierarchies. Following in the footsteps of the baroque carnival and its profusion of musical, theatrical, or nautical spectacles present well beyond the winter period, the collective festive culture of the second half of the seventeenth century and of the eighteenth century stood out not only because of its ethics of pleasure, deemed to be a defining characteristic of Venice, but also because of its encouragement of the art of conversing, the regulation of passions, and the practice of concealment with a view to preserving the interests of the republic and its socially pacified image. During the era that I have dubbed "Republic of the Masks" in my history of Venetian Carnival, state surveillance was exercised over the masks for about four months of the year, well beyond the ten days leading up to Lent. ${ }^{26}$

Indeed, after adjustments consolidated the political and social vocation of carnival in the first quarter of the sixteenth century, the "time of masks" ultimately came to refer to the period during which profane shows and spectacles were authorized as the theater season. That season extended from the beginning of October to Advent, from the Feast of Saint Stephen (the day after Christmas) to Fat Tuesday (Mardi Gras, or Shrove Tuesday), and finally for the fortnight around the Feast of Ascension, "so that" the magistrate and man of letters, Charles de Brosses, wrote in 


\section{$J O U R N A L$ \\ OF FESTIVE}

\section{STUDIES}

27. Charles de Brosses, Lettres d'Italie (1799; Paris: Mercure de France, 1986), 242.

28. Montesquieu, Mes voyages, ed. Jean Ehrard, with the collaboration of Gilles Bertrand (Paris: Classiques Garnier; Lyon: ENS Editions, 2012); Cardinal de Bernis, Mémoires et lettres, ed.

Frédéric Masson (Paris: Plon, 1878); and Jean-Claude Richard, Abbé de Saint-Non, Panopticon italiano: Un diario di viaggio ritrovato, 1759-1761 (Rome: Ed. dell'elefante, 1986).

29. Braudel himself wrote about the "mixing of social conditions" in Enlightenment Venice. See Fernand Braudel, Le modèle italien (Paris: Arthaud, 1989). Originally published in 1974 under the title "L'Italia fuori d'Italia. Due secoli e tre Italie," in Storia d'Italia, vol. 2, Dalla caduta dellimpero romano al secolo XVIII, ed. Ruggero Romano, Corrado Vivanti (Turin: Einaudi, 1974), 2092-2248. This idea can also be found in Braudel, Venise (Paris: Arthaud, 1984), 102.

30. Giovanni Rossi, Costumi Veneziani, vol. 11, Cod. Marc. It. VII 1396 (9287), folio 149, Biblioteca Marciana, Venice.
1739 with slight exaggeration, "one can therefore count about six months when everyone goes about masked, priests as well as others, even the Nuncio and the Superior of the Capucines." ${ }^{27}$ Such an extension of carnival time seriously challenged the ordinary definition of carnival as "time out of time." What was the status of a pleasure that was becoming so diluted? Travelers such as Montesquieu and then those of the second half of the eighteenth century, from Cardinal de Bernis to Jean-Claude Richard, Abbé de Saint-Non, often emphasized the boredom and monotony of this prolonged carnival season, during which they felt excluded from Venetian society. ${ }^{28}$

In the eighteenth century, masks were also used in ceremonies greeting ambassadors and at the five ritual grand banquets offered each year to Venetian dignitaries by the doge. These banquets, which the people could attend until the end of the first course, were held on Saint Mark's Day (San Marco being the patron saint of the city), Ascension Day, Saint Vito's Day (the day when Baiamonte Tiepolo's conspiracy was discovered), Saint Jerome's Day (the day when the Great Council renewed the elections of the magistrates), and Saint Stephen's Day (to commemorate the transfer of the protomartyr's relics from Constantinople to Venice). Related to sumptuary laws, masks limited the conspicuous display of luxurious clothing in the name of republican (and gender) equality while making the wearers incognito, and thus immunity from prosecution.

Over the course of the century, out of the diversity of the masks, a particular form of carnival costume worn by the elite was gradually forged, namely, the future bautta. A guild of mask makers, whose professional album (mariegola) for the 1430-1620 period has been preserved, had been producing masks since the fifteenth century. After working inside the painters' guild alongside sign makers using papier mâché, they set up an independent corporation in 1683 that included papermakers, gilders, miniaturists, and makers of gold leaf-embossed leather. In 1773, the eighteen master mask makers, seven journeymen, and six apprentices formed a protected group that was well established.

If the republic encouraged Venetian noblemen and noblewomen to wear the costume made up of a white mask (volto), a tricorn, a bautta, and a loose-fitting cloak (the tabarro) in the eighteenth century, it was primarily to allow the dwindling aristocracy to conceal their identities behind an outfit common to many cittadini. It was also a way for Venice to limit the circulation of information between the nobility and foreigners, in particular diplomats (since everyone was masked, the latter could not know who they were talking to) (fig. 7).

However, far from mixing up social conditions entirely, as commonly thought, the bautta costume also worked as a social marker. ${ }^{29}$ Subtle differences between noble and non-noble (cittadini or popolani), such as the way the tricorn was positioned alla forestiera or il bautino calato (the shawl falling onto the shoulders, as foreigners wore it during the Feast of Ascension to escape the heat), made it possible to temporarily avoid the breakdown of social barriers (fig. 8). In the bull hunts, the nobility wore white so that they could be distinguished from the common people and, as scholar Rossi pointed out in a manuscript from the 1840s, the bautta mask worn by the nobility contrasted with the predominant maschere buffe (playful masks). ${ }^{30}$ 


\section{$J O U R N A L$ \\ OF FESTIVE \\ STUDIES}

31. Casini were small private apartments where Venetian nobles met, conversed, or played with friends.

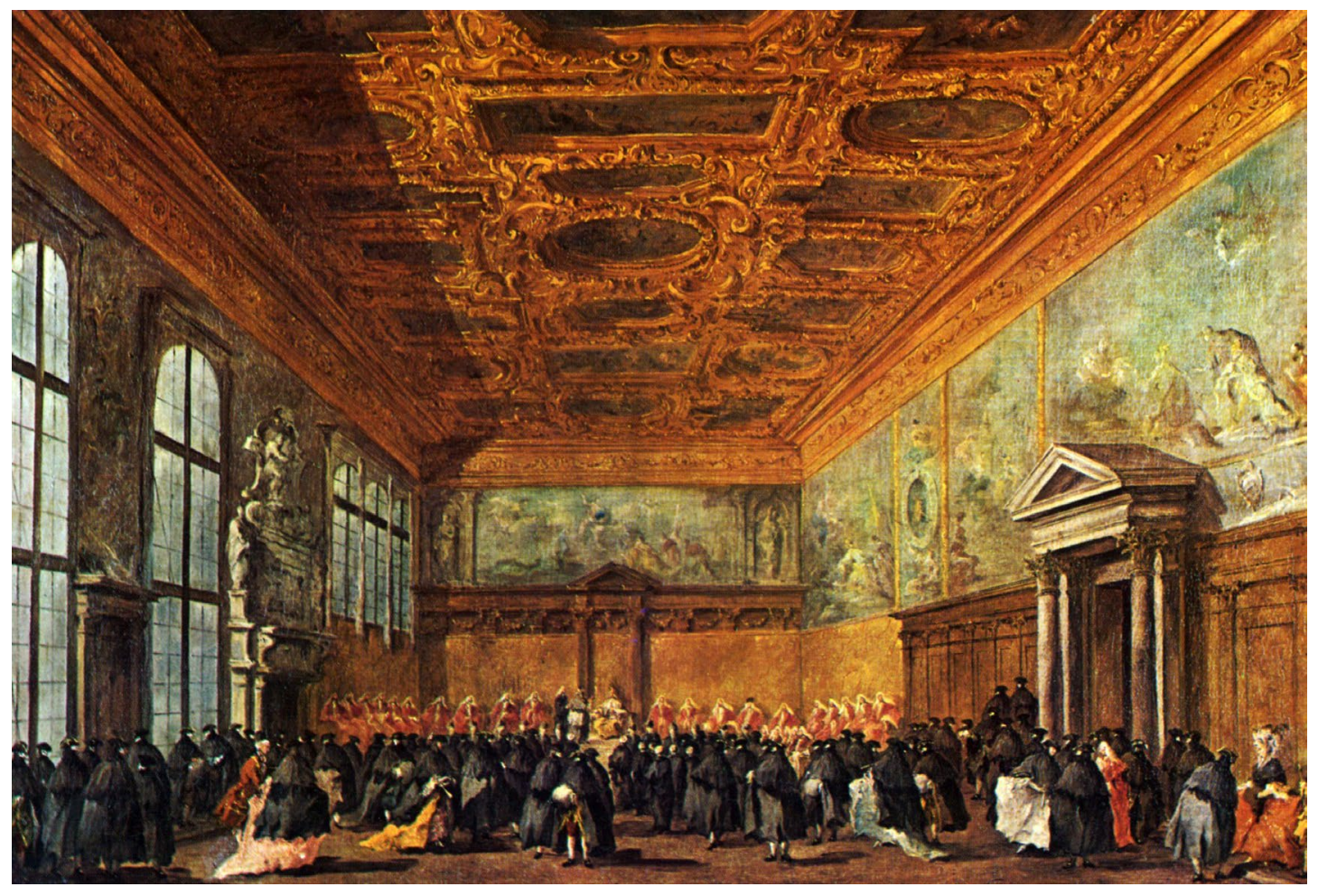

Figure 7. Francesco Guardi (1712-93), Audience Granted by the Doge in the Hall of the College of the Ducal Palace, 1770. Oil on canvas. Musée du Louvre, Paris.

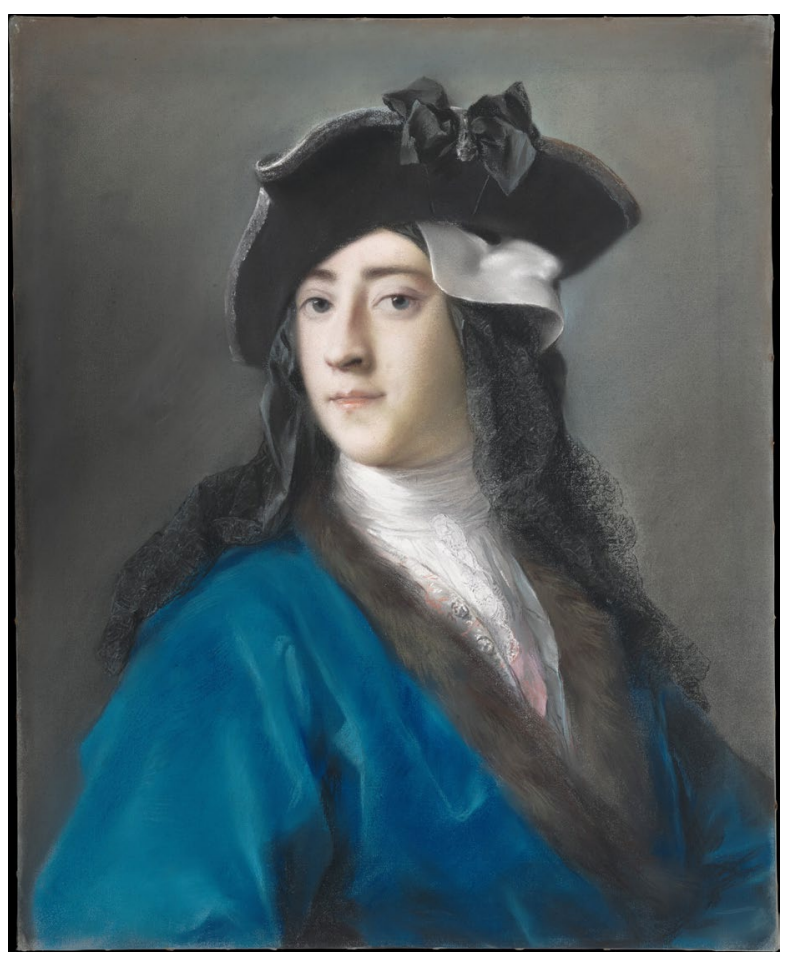

Figure 8. Rosalba Carriera (1675-1757), Masquerade Costume Portrait of Gustavus Hamilton, 2nd Viscount Boyne (1710-1746), between 1730 and 1731. Pastel on paper, laid down on canvas. Metropolitan Museum of Art, New York.

Poles apart from the idea of carnivalesque transgression, the Venetian mask was in fact used to moralize social life, regulate admission to theaters, and confine pleasures to closely supervised places, such as the ridotti, casini, cafés, and gambling dens ${ }^{31}$ Admittedly, the difficulty of keeping misbehavior under control is attested by the repetition, throughout the modern era, of Council of 


\section{$J O U R N A L$ \\ OF FESTIVE}

\section{STUDIES}

32. The reference edition to Casanova's memoirs is Histoire de ma vie, 12 vols. (Wiesbaden: F. A. Brockhaus, 1960-62).

33. Gilles Fermanel, Robert Fauvel, Baudouin de Launay, and

Vincent Stochove, Le voyage d'Italie et du Levant (Rouen: C.

Maurry, 1670), 467; and Alex-

andre-Toussaint Limojon de Saint-Disdier, La ville et la République de Venise (Paris: Guillaume de Luyne, 1680), 410.

34. See Carlo Goldoni, Villeggiatura trilogy, trans. Robert Cornth-

waite (Lyme, NH: Smith and Kraus, 1994); and Antonio Longo,

Memorie della vita di Antonio Longo viniziano scritte e pubblicate da lui medesimo per umilta

(Venice: Antonio Curti, 1820).

35. Gabriel-François Coyer, Voyages d'Italie et de Hollande, 2 vols. (Paris: Duchesne, 1775). On carnival crowds in Venice, see Bertrand, Histoire du Carnaval de Venise, 47-48.
Ten edicts prohibiting maskers from carrying weapons, gambling to excess, wearing luxurious items of clothing, entering monasteries and churches, wandering about at night, and dressing as women. The authorities - with the aid of such "spies" as Casanova-insisted nonetheless on tracking down any action indicative of moral looseness. ${ }^{32}$ Courtesans attracted foreigners, and gambling, it was said, was ruining Venetians. Ten years after closing the private ridotti in 1628, the government opened a public gambling room, the Ridotto di San Moisè, where players had to wear masks (fig. 9).

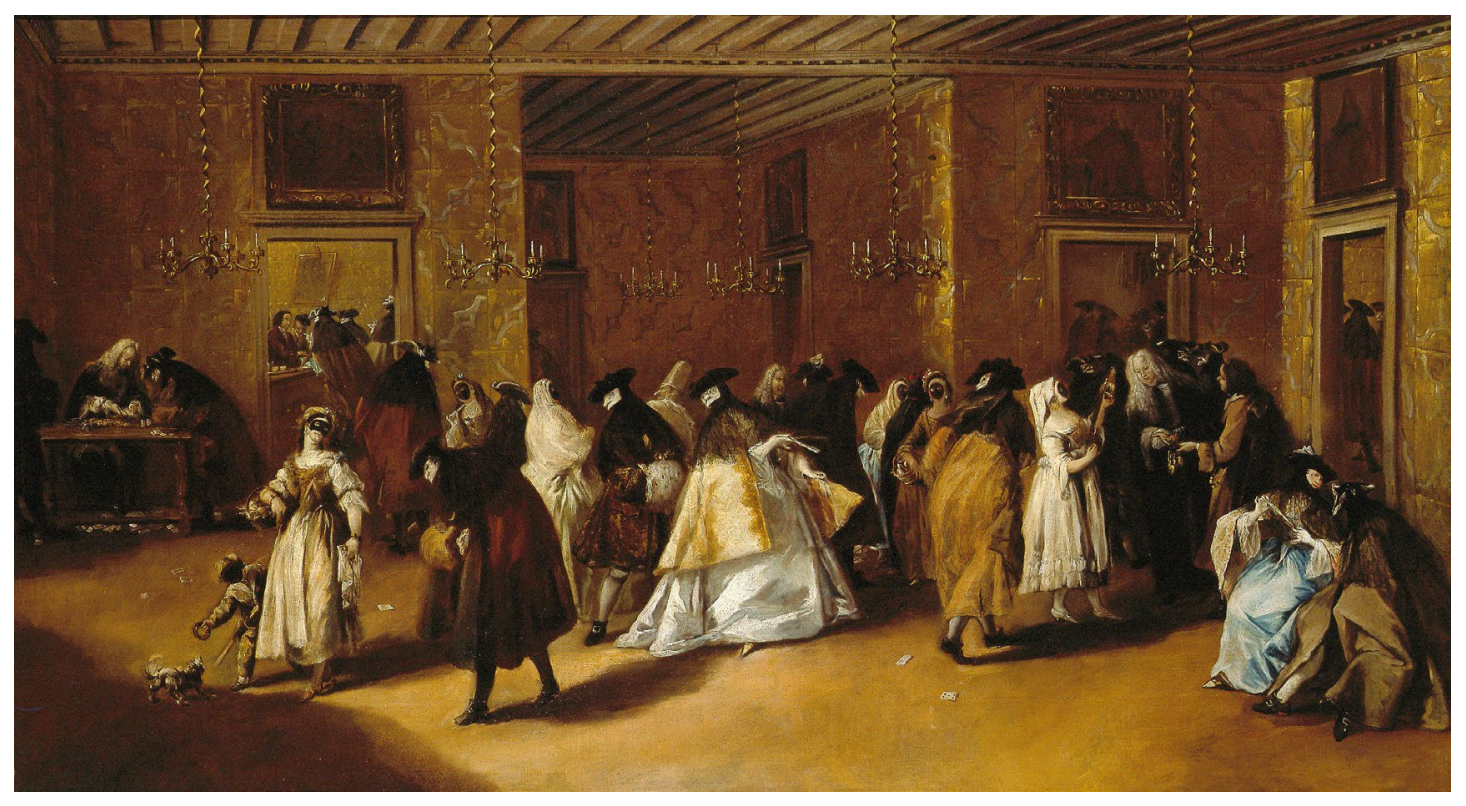

Figure 9. Francesco Guardi (1712-93), The Ridotto of San Moise, 1746. Oil on canvas. Ca' Rezzonico, Venice.

Gambling was done there in silence, on authorized days, and bankers were selected among nonmasked patricians to limit the risks of fraud. The state controlled the activities of all those who occupied a spot on St. Mark's Square, from charlatans to preachers.

Behind the façade of a gentle, submissive people, bound together in perfect harmony, the republic had, in fact, never solved the problem of violence that plagued agrarian carnivals. Regardless of the effectiveness of urban policing and the image of civility that Venice embodied abroad, the gap between the people and the elite had kept growing between the sixteenth and eighteenth centuries. In the sixteenth century, the nobility had started organizing private banquets that protected them from the rabble. In the early seventeenth century, travelers like Gilles Fermanel had been struck by "the incredibly large quantity of disguised people" on St. Mark's Square, which, according to Alexandre-Toussaint Limojon de Saint-Disdier in 1680, "could hardly contain the crowd of masks and of those who come to see them." ${ }^{33}$ In the second half of the eighteenth century, they took refuge in their country villas, such as those on the Riviera del Brenta depicted by Carlo Goldoni and Antonio Longo in his memoirs. ${ }^{34}$ Perceived as tiresome rather than threatening, the crowds were deemed calm by Ambassador Bernis in 1752-55, dull by Saint-Non in 1761, and varied in its disguises by Abbot Gabriel-François Coyer in 1763. ${ }^{35}$ But they could become dangerous in a space ill-suited to such a congregation of people. To allow the city to breathe, Napoleon I created the Venice Giardini, and in 1854, one year before work on the Lido began, plans were made (but never carried out) for a gigantic seaside resort called the 


\section{$J O U R N A L$ \\ OF FESTIVE \\ STUDIES}

36. Maximilien Misson, Nouveau

Voyage d'Italie, fait en l'année 1688, avec un mémoire contenant des avis utiles à ceux qui voudront faire le mesme voyage (La Haye: $H$. van Bulderen, 1691), 1:169. This formula was taken up verbatim by de Brosses in his letter to $M$. de Blancey dated August 13, 1739, in ibid., 190-92.

37. For more details on this controversy, see Gigliola Fragnito and Alain Tallon, eds., Hétérodoxies croisées, catholicismes pluriels entre France et Italie, XVIe-XVIle siècles (Rome: École française de Rome, 2017).
"Royal Palace" on the Riva degli Schiavoni waterfront. Not until art collector and decorator Carlos de Beistegui's flamboyant 1951 masked costume ball at the Palazzo Labia would the city attempt to reestablish communication between private partying in palaces and popular festivities. Even after the return of the carnival in 1980, the collateral damage caused by the crowds on St. Mark's Square generated so much criticism that the alderman Maurizio Cecconi imposed a one-way system for pedestrians in 1985.

Modern-era carnival fulfilled paradoxical functions, therefore. Beyond the entertainment and libertinage lay both a concern for security and a fear of reform. The anxieties of an inwardlooking society ultimately resulted in encouraging licentiousness and pleasures, provided they did not call authority into question. "Do what you please provided that you do not flout the boundaries of [religious and political] decency," summed up French traveler Maximilien Misson in $1691 .{ }^{36}$ On the fringes of public space, a private space was being constructed where freedom was total, so that the paradox consisted in encouraging licentiousness while also combating it. On the one hand, masks were turned into an accessory for pleasure, as Casanova's memoirs amply recounted; on the other hand, the state combated dissolution and sought to maintain law and order in Venice by using masks as instruments of political control. As for the church's moralizing discourse on carnival, it bothered people little in Venice: the authorities had been used to distancing themselves from papal authority since the controversy that pitted Pope Paul $V$ against theologian Paolo Sarpi in 1606. ${ }^{37}$ Alongside these "functional" uses, carnival and its masks provided occasions for displays of creativity in the fields of music (Francesco Gasparini, Antonio Vivaldi, Baldassare Galuppi, Giovanni Paisiello); the theater (Goldoni); and above all painting, with Pietro Longhi, Francesco Guardi, and Giandomenico Tiepolo.

\section{A Low-Key Festival Reflective of Venice's New Political Status after 1797}

In the last section of this article, I want to reflect on the survival and evolution of Venetian Carnival beyond the eighteenth century. After the Enlightenment peak of carnivalesque fever, the pre-Lenten celebrations that had enjoyed so much success since the Middle Ages had to adapt to the city's loss of independence after 1797. Venice Carnival could no longer serve to highlight the power of the aristocratic republic. What did it celebrate once Venice was no longer the heart of an autonomous state? What new political needs (if any) has it been meeting up until the present day?

In the first half of the nineteenth century, carnival was radically transformed in a context of submission to foreign powers-France in 1797 and from 1805 to 1814, and Austria from 1797 to 1805 , from 1815 to 1848 , and from 1849 to 1866 -followed by integration into a new unified Italian state, the Kingdom of Italy (1861-1946). More than ever before, it was characterized by a retreat into private parties and by a primacy of imagination and memory over reality. Such features would later facilitate its commodification by the tourism industry at the end of the twentieth century and beginning of the twenty-first century.

After a short moralizing pause (1802-16) during which entertainment deemed the most threatening to public order and safety was suppressed, the third decade of the nineteenth century saw the return of balls, spectacles, shows, and masquerades. Costumes enlivened the city in the run-up to Lent again, but, above all, carnival punctuated the theatrical and musical 


\section{$J O U R N A L$ \\ OF FESTIVE \\ STUDIES}

38. George Sand to Jules Boucoiran [Venice], January 28 [1834], in Correspondance, vol. 2, (1832-

June 1835), ed. Georges Lubin (Paris: Garnier frères, 1966), 480. season. It briefly acquired a political function again in the winter of 1867 , when in the presence of the mythical hero of the Italian Risorgimento, General Giuseppe Garibaldi, and the king's son, Amedeo, Duke of Aosta, a moment of collective fervor turned the city into an epicenter of the new Italian patriotism. But enthusiasm for carnival did not last, and the following celebrations were lower key. Above all, following the $9^{\text {th }}$ Congress of Italian Scientists in 1847 and the establishment of the Venice Biennale in 1895, the city's festive center of gravity shifted to seasons other than that of the Old Carnival.

For most writers, including Lord Byron and other Romantic poets, Venice was in fact associated with mourning rather than unbridled carnivalesque joy in the nineteenth century. In his 1825 series of engravings titled Un mois à Venise, Louis de Forbin contrasted the horror of old Venetian prisons and the city's festive pleasures. Painters Longhi and Guardi were no longer discussed until the 1840s. Carnival did not disappear entirely, but since the city was no longer able to celebrate its power, the commemorative system into which masquerades fit was devoid of its prior meaning. The festivals henceforth honored only foreign sovereigns. Winter carnival and even Ascension carnival were no longer the highlight of festive life, since the Festa del Redentore (Feast of the Most Holy Redeemer) took over this role on the third Sunday in July and henceforth attracted princely visitors in the summer. A clear sign of the embourgeoisement of the festivities was the disappearance of acrobatic feats in favor of the quiet pleasure of walking along the Riva degli Schiavoni. The bucentaur, robbed of its mast and mutilated, became a floating penitentiary. Street spectacles disappeared, as did the bautte, and novelist George Sand could not hide her disappointment after attending carnival in 1834: "Every Sunday we have masks on the docks and in the square.... They arrive on the lagoon in decorated boats, along with musicians. It pales by comparison with the fantastic descriptions we hear of ancient Venice and its festivals, and yet it is still beautiful enough to our Parisian eyes." ${ }^{38}$

Of the apogee of Venetian Carnival, there remained few traces in the nineteenth century. Trestle stages were still erected on the Riva degli Schiavoni, close to the Ducal Palace. In 1818, they accommodated an elephant that, once carnival was over, escaped and fled through the little streets called calli in Venice until it was finally dispatched by a blast of cannon fire. Aside from ballets, puppet shows, and plays in Italian or in local dialect, operas by Rossini, Bellini, Donizetti, and Verdi, which all premiered at the La Fenice Theatre during carnival, confirmed Venice's vocation as musical capital. Lavish balls continued to be held at the salons of the Società Apollinea. Venetian high society found refuge in these pleasures, to which foreigners were no longer necessarily invited.

Although a carnival did exist in the nineteenth century, it was so different as to challenge our conception of the political entirely. Indeed, after foreigners like the Duchess of Berry and the Count of Chambord started purchasing Venetian palaces where they organized parties for the upper crust in the 1840s, carnival stopped being a festival for the entire city, and in the last decades of the nineteenth century, it even deserted the ballrooms and concert halls. This withdrawal from the public sphere was paralleled by a desire to memorialize and reenact Enlightenment-era carnival. Among such reenactments was the masquerade in bautte that was organized in 1899 by the Prince of Hohenlohe-Waldembourg and artist and fashion designer Mariano Fortuny, which became famous throughout Italy and was immortalized in his 1911 


\section{$J O U R N A L$ \\ OF FESTIVE}

\section{STUDIES}

39. Edmond and Jules de Goncourt, L'Italie d'hier, Henri de

Régnier, Esquisses vénitiennes (Paris: L’Art décoratif, 1906); Henri de Régnier, L'Altana, ou la vie vénitienne (Paris: Mercure de France,

1928); Aloysius Bertrand, "La chanson du masque," in Gaspard de la nuit: Fantaisies à la manière de Rembrandt et de Callot, bk. 5, ed. Louis Bertrand (Paris: Labitte; Angers: V. Pavie, 1842) (this was a posthumous volume, the author

having died in 1841); Maurice

Sand, Masques et bouffons: Comédie italienne (Paris: MichelLévy frères, 1860); and Théophile

Gautier, Italia (Paris: V. Lecou, 1852).

40. On these nineteenth-century painters, see Giuseppe Pavanello and Giandomenico Romanelli, eds., Venezia nell'Ottocento: Immagini e mito (Milan: Electa, 1983).

41. Philippe Monnier's book was already in its sixteenth edition in 1937. It has been successively published by Payot, Perrin, Club du meilleur livre, Editions Complexe, and now Tallandier. Philippe

Sollers, La Fête à Venise (Paris:

Gallimard, 1991); and Philippe Sollers, Dictionnaire amoureux de Venise (Paris: Plon, 2004). book, Sous le manteau vénitien: Silhouettes de la fin du XVIIle siècle (Under the Venetian cloak: Silhouettes of the late $18^{\text {th }}$ century).

Such nostalgia for carnival in its eighteenth-century incarnation was the result of substantial research conducted between the 1850s and the 1920s by such Venetian scholars as Molmenti as well as by foreign writers. The Goncourt brothers and Henri de Régnier, for instance, promoted Longhi as "the painter of carnival," and meditation on the Venetian mask was a lasting topos of nineteenth-century literature, from Aloysius Bertrand with "La chanson du masque" (the song of the mask) to George (and Maurice) Sand, from Théophile Gautier to Austrian writers who, in the late nineteenth century, sensed the impending collapse of the Austro-Hungarian Empire. ${ }^{39}$ The myth of Venetian Carnival thus fueled an obsession with political decadence. Meanwhile, Italian painters, such as Ippolito Caffi, Giacomo Favretto, and Vittorio Emanuele Bressanin (fig. 10), also cultivated a form of patriotic nostalgia. ${ }^{40}$

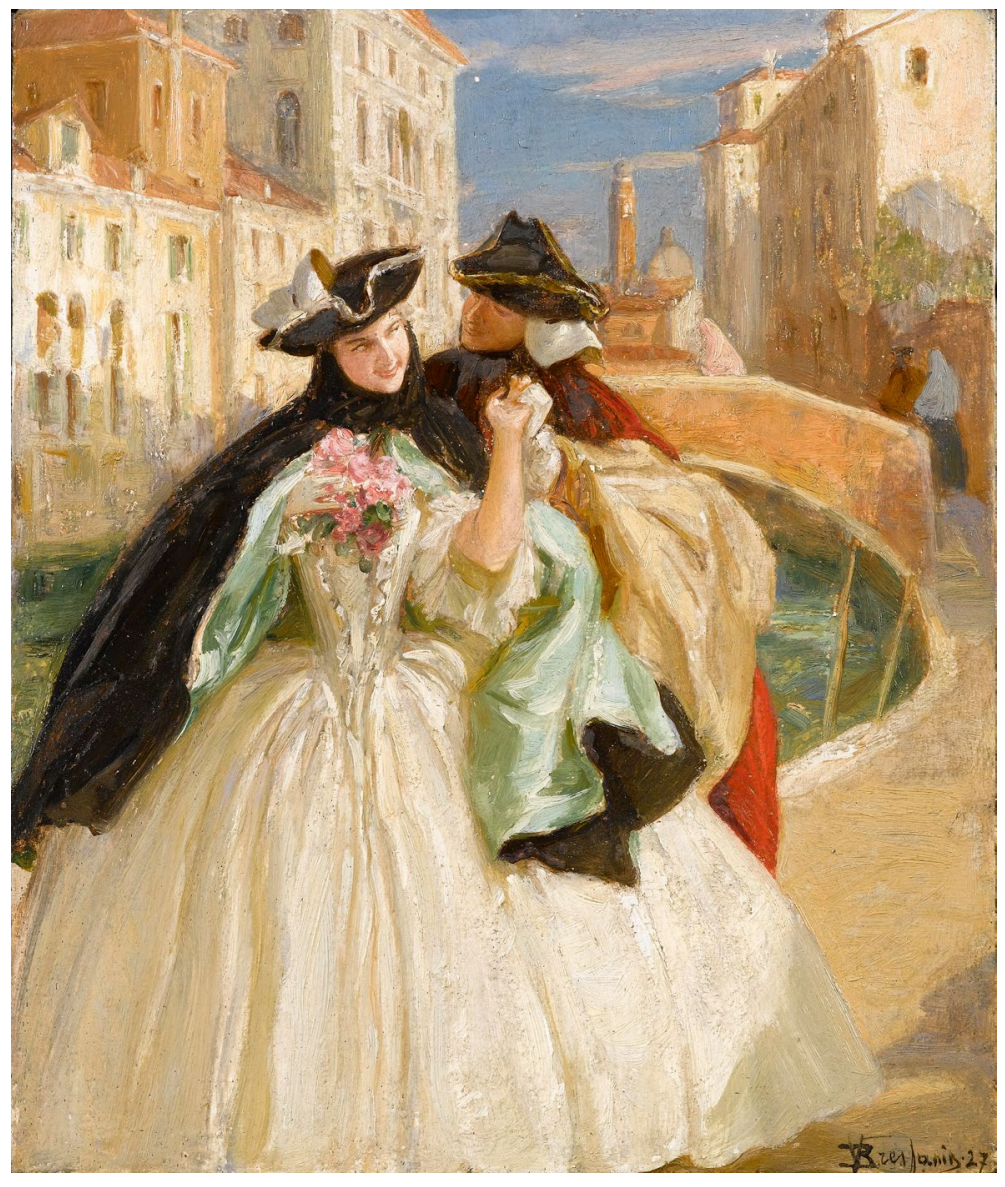

Figure 10. Vittorio Emanuele Bressanin (1860-1941), Carnival in Venice, signed and dated V. Bressanin (19)27. Oil on wood. Location unknown.
Nowhere was nostalgia for eighteenth-century Venetian Carnival stronger than in late nineteenthcentury France, when champions of a "masculine" and "energetic" Third Republic deplored the vanishing pleasures of carnival. Even today, the French-speaking Swiss writer Philippe Monnier's 1907 book Venise au XVIIle siècle (published in English in 1910 as Venice in the Eighteenth Century) continues to sell well, while the success of the essayist Philippe Sollers's La Fête à Venise (1991) and Dictionnaire amoureux de Venise (2004) testifies to the durability of stereotypes forged in the 1880s. ${ }^{41}$ 


\section{$J O U R N A L$ \\ OF FESTIVE}

\section{STUDIES}

42. Indeed a PhD dissertation

has used this title. See Louise-Marie Morgant, "Venise et ses masques: Étude de la résurgence du carnaval vénitien" (PhD diss., University of Rennes, 1987, Lille: Atelier National de Reproduction des Thèses).

43. Élisabeth Crouzet-Pavan, "Dynamiques de langages: Pour une relecture du système rituel vénitien (XIIIe-XVe siècle)," in

Le destin des rituels: Faire

corps dans l'espace urbain, Italie-France-Allemagne, ed. Gilles Bertrand and Ilaria Taddei (Rome: École française de Rome, 2008), 95-115, esp. 96.

44. Filippo Mariani, Francesco Stocco, and Giorgio Crovato, La reinvenzione di Venezia: Tradizioni cittadine negli anni ruggenti (Padua: II Poligrafo, 2007). See, in particular, the preface by Marco Fincardi, 9-16.

45. On the metamorphoses of the Unità festival, that is, of the Italian Communist Party in the 1970s, see Anna Tonelli, Falce e tortello: Storia politica e sociale delle feste dell'Unità (1945-2011) (RomeBari: Laterza, 2012).
In the twentieth century, carnival came to be associated with the words "death," "survival," and "resurgence," as if it were a stable social phenomenon passed from generation to generation. ${ }^{42}$ This idea that carnival had a structure and a foundation date, and then developed to reach a zenith before slowly declining, always pointed to the eighteenth century as a crowning point. This owed much to the "gradual ceremonial glaciation of the modern era" observed by Crouzet-Pavan and to the publicity that Venice Carnival attracted after the seventeenth century. ${ }^{43}$ Compared with the flamboyant festivities of the seventeenth and eighteenth centuries, twentieth-century Venetian Carnival could not fail to disappoint. Against this scenario of decline, however, I believe that the "plasticity" of Venetian ceremonial culture, its capacity to adapt unceasingly to meet new needs, must be further investigated. Like all Venetian rituals, carnival has constantly morphed, and despite its apparent weakening after 1797, it may simply have adopted a new mask in the twentieth century.

Admittedly, carnival was less visible after World War I. But the idea that it disappeared entirely from Venice's festive landscape does not stand. One of the forms under which it survived was as an artistic display of creativity centering on the world of princely palaces, stimulated by rich patrons, and expressing itself both in summer and in winter. One of the most famous masked balls, the "Longhi ball" organized by Marchesa Casati, thus took place in August and September 1913.

Under the fascist regime, with its tendency to "reinvent" urban traditions, carnival survived not as a street celebration but as a social event tinged with charity, traces of which could be seen in the pomp and ceremony that accompanied the Biennale's art exhibitions and the film festival launched in $1932 .{ }^{44}$ In the 1950s, carnival culture continued to inspire local society figures, such as Carlos de Beistigui. For his September 3, 1951, ball at the Palazzo Labia, the multimillionaire art collector asked his friends Emilio Terry, Salvador Dali, and Christian Dior to create scenery and costumes evocative of Longhi and Casanova's times. The result was striking, from the entrance of long thin giants on stilts wearing the bautta to the Hercules's Strength human pyramids featuring the Venice fire brigade dressed as Harlequins. Eventually, a series of artistic events paved the way for its return in 1980 as a spectacle directed by stage and film director Maurizio Scaparro: the creation of the environmentally friendly Vogalonga rowing regatta in 1974; choreographer Maurice Béjart's 1975 dance performance; the new festival model of the Unità, which revived the taste for the ephemeral and for theater disseminated all over the city's squares; and the success of Fellini's Casanova in 1976 and Aldo Rossi's Teatro del Mondo in 1979.45

Throughout the twentieth century, carnival also continued to irrigate graphic and plastic arts production. Georges Barbier's drawings of Romantic and polite Venice, contemporaneous with Henry Régnier's L'Altana ou la vie vénitienne (1928), or the pictures of such 1980s photographers as Fulvio Roiter and his disciples were not merely the products of nostalgia. Rather, they testified to the fact that Venice Carnival had left the sphere of politics to become a major driver of artistic creation.

Parallel to this dual process of privatization and of creativity, carnival changed over the course of the twentieth century into a carnival of memory, boosted by a 1937 retrospective on "Venetian festivals and masks" at the Ca' Rezzonico, a palace that had just been acquired by the city of Venice to house eighteenth-century art collections. After World War II, a series of exhibitions 


\section{$J O U R N A L$ \\ OF FESTIVE}

STUDIES

46. See Alessandro Bressanello, II carnevale in età moderna: 30 anni di carnevale a Venezia 1980-2010 (Venice: Studio LT2, 2010). On the revitalization of European festivals after World War II in places other than Venice, see Jeremy Boissevain, ed., Revitalizing European Rituals (London: Routledge, 1992); and Laurent-Sébastien Fournier,

"Traditional Festivals: From European Ethnology to Festive Studies," Journal of Festive Studies 1, no. 1 (Spring 2019): 11-26. On the opposite thesis of continuity in European ritual, see Jeremy MacClancy and Robert Parkin,

"Revitalization or Continuity in European Ritual? The Case of San Bessu," The Journal of the Royal Anthropological Institute 3, no. 1 (March 1997): 61-78. focused on carnival masks and "carnival painters," including Giovanni Antonio Canal, known as Canaletto, the Guardi brothers, Pietro Longhi, and Gabriele Bella. Building on Venetian scholarly research of the nineteenth century, the twentieth century cultivated a largely philological interest in carnival, haunted by evocations of a supposed past golden age. Stripped of the disapproving, moralizing tone of nineteenth-century scholarship, however, the reference to Casanova and to the entertainment fever of the eighteenth century imbued the carnival practices of the late twentieth century with a sort of vital and liberating impetus that would be one of the determinants of its return.

Finally, twentieth-century carnival, like many other leisure activities, testified to the effects of commodification, which in Venice started with the creation of a road bridge in 1933 that supplemented the 1846 rail bridge. As "authentic" as the 1980 resurrection of carnival may have initially been perceived by the Venetians and foreigners who found themselves together again in the streets and palaces, this collective moment combining theatrical or musical performances with anonymous costumed players wandering about in search of an audience soon submitted to commercial imperatives, as the official programming devised by the authorities increasingly made clear. ${ }^{46}$

Today, Venetian Carnival juxtaposes the masked balls put on at great expense in aristocratic palaces with the return of the "Flight of the Angel" (now augmented with a "flight of the lion" and "flight of the eagle") after more than two hundred years of absence. The advent of digital photography and social media has granted carnival a visual and instantaneous dimension, which might suggest a return to a baroque form of aesthetics if it were not deprived of a driving force, at the behest of which carnival would take place. Venice today is no longer ruled by a sovereign, unless one considers that the Consorzio Venezia Nuova and the bodies regulating the tourist trade perform that function.

Having lost its nineteenth-century ability to showcase the perfection of Venetian republican institutions to the rest of the world, contemporary carnival has thus become a combination of private parties highlighting the creative potential of artists and rites of mass consumption subject to festive dilution despite the reestablishment of the holiday in February. It mostly endures through photography, through the year-round exhibition of masks in shop windows, and through the image of the city promoted in touristic pamphlets. Faced with a myriad of street vendors selling the same glittering masks devoid of any philological intent, Venetians find it hard to identify what was and what could still be "their" carnival. Hence this paradox: on the one hand, carnival festivities have become omnipresent, with masks being visible in all seasons in Venice and in the advertisements intended to attract tourists; on the other hand, they are nowhere to be found, insofar as everyone desperately tries to locate the "true" carnival behind centuries of narratives and images. This paradox notwithstanding, the enigmatic Carnival of Venice remains a vibrant festival that feeds on people's desires and dreams, thus testifying to the power of images (fig. 11). 


\section{$J O U R N A L$ \\ OF FESTIVE}

STUDIES

47. The contrast was made especially obvious by the 2014 exhibition on European carnivals organized by the MuCEM (Museum of European and Mediterranean Civilizations) in Marseille. See Marie-Pascale Mallé, ed., Le monde à l'envers: Carnavals et mascarades d'Europe et de Méditerranée (Paris: Flammarion; Marseille: MuCEM, 2014).

48. Mikhail Bakhtin, Rabelais and His World (1968; Bloomington: Indiana University Press, 1984); and Carlo Baroja, El Carnaval: Análisis histórico-cultural (Madrid: Taurus, 1965).

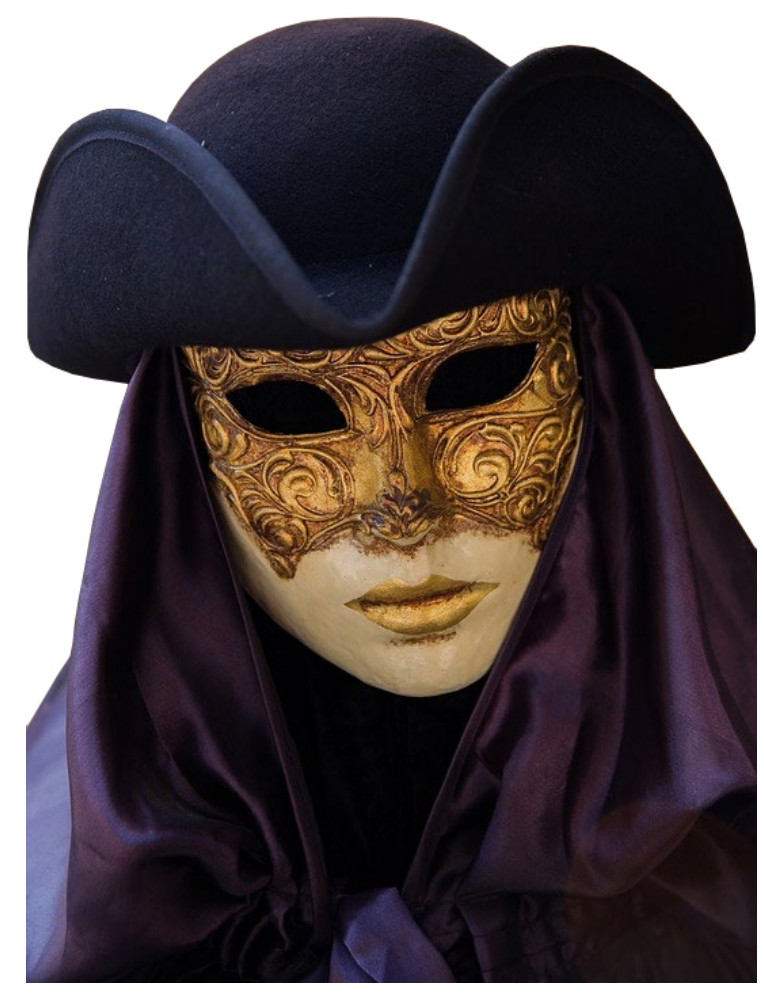

Figure 11. Anonymous, Venice Carnival costume with mask and hat, 2017. Source: Wikimedia Commons.

\section{Conclusion}

In the Middle Ages, Venice Carnival developed a unique set of characteristics that came to distinguish it from other European carnivals, both urban and rural. ${ }^{47}$ In the centuries that followed, two forms of festivity actually coexisted within it: a popular one-relatively invisible but intent on breaking away from the hardships of daily life, in line with literary critic Mikhail Bakhtin and anthropologist Carlo Baroja's theoretical models-and an upper-class one that sought to address the needs expressed by the common people while continuously distancing from them. ${ }^{48}$ The gap between both was manifested during the sixteenth century in the organization of exclusive, aristocratic banquets and in the eighteenth century in the nobles' escape from crowded places to their villas on the banks of the Brenta River during carnival time. Meanwhile, carnival became a political instrument for the Republic of Venice. Having been used to emphasize Venetian domination in the face of European competitors in the fifteenth and sixteenth centuries, it allowed local artists to showcase the greatness of La Serenissima and conceal its weakening on the European stage in the seventeenth and eighteenth centuries.

Today, Venetian Carnival still constitutes a major reference in the global panorama of carnivals. It owes its popularity to its conversion into a commercial, touristic festivity, to the enduring need for citizens around the world to escape everyday drabness and grayness, and to its capacity to "recall" the past. Even though the historical reference is fading from year to year in the current carnival-to wit the theme chosen in 2015, "The world's most delicious festival"-it maintains a strong connection with the past of the Venetian Republic, if only due to the surrounding urban and architectural scenery.

Taking the long view when discussing Venice Carnival is an invitation to reflect on the gap that exists between its medieval form and its more recent configuration, as well as on the various 


\section{J O U R N L L OF FESTIVE} STUDIES

49. Terry Eagleton, Walter Benjamin, or Towards a Revolutionary Criticism (1981; New York: Verso Books, 2009).

50. Gino Benzoni, "Sfiorata l'utopia? Tra autoconsiderazione dello Stato marciano nel '500 e autoillusioni accademiche," in L'utopia di cuccagna tra '500 e '700: II caso della Fratta nel Polesine, ed. Achille Olivieri and Massimo Rinaldi (Rovigo: Minelliana, 2011), 15-51. functions the event has performed over time. At times, it has been a major source of civic cohesion, allowing residents to rub shoulders and brush past one another in alleyways, on bridges, on small squares, or on the expansive St. Mark's Square, where they converged to show off. At others, it has acted as a liberating safety valve, allowing for temporary transgression within a strict political and social framework. In the seventeenth century, for instance, it fit in a logic of social control and of policing of pleasures that hardly enabled it to be more an authorized break from hegemony. ${ }^{49}$ At yet during other periods, it has been used by the elites as a showcase for Venetian splendor in a context of increasing competition between European cities. In the early modern era, its commodification thus turned it into a major source of revenue for the city. Throughout its history, however, it seems to have had a powerful commemorative and narrative dimension. It has indeed been a crucial part of the story Venice has devised about itself. Venice may no longer be Queen of the Seas, but carnival has allowed it to preserve its capacity to inspire and fascinate down to the age of mass tourism. Additionally, carnival has long entertained a relationship with curiosity, including scientific curiosity, and with unknown and exotic worlds, as revealed by the success of the Mondo Novo street plays performed on St. Mark's Square in the eighteenth century. Last but not least, one dimension that has stood the test of time is the utopian dimension of carnival, which transcends economic conditioning and tourism packaging. Venetian Carnival leads us back to Benzoni's concept of Venice as a "realized utopia," a sort of heaven on earth born from Erasmus's sixteenth-century utopian program and from the city's creative strength. ${ }^{50}$ One can indeed find traces of Venice's capacity to fabricate space down to today's revived carnival, based on a power that, while being linked to the powers of the market economy, remains invisible and impossible to represent.

One question that this article does not presume to answer is the following: is the political dimension of the Carnival of Venice limited to the role that it played at the time of the Serenissima Republic, a paradoxical moment of putting in order the various categories of the population that took part in it-the nobility, the cittadini, the popolani-while foreigners flocked there from afar? In other words, is the political dimension of carnival a mere memory that, admittedly, can be awoken but remains a prisoner of history? Or conversely, does the way it is perceived and experienced today lead us to see the enduring nature of its power, which would continue to act through a form of dramatization and distancing that the mask would make possible?

The cancellation of the carnival festivities during the Gulf War in 1991, the debates that its organization generates every year among Venetian politicians, the impatience it creates among Venetians due to the fact that it has become a moment of tourist consumption that, in many ways, escapes them: all of these show that carnival still has an impact on collective life. However watered-down or questionable its manifestations might appear today in their commercial ritualization and loss of spontaneity, carnival continues to raise eminently political questions: Who produces it? Who gets to have fun? What purpose does it serve? What spaces for imagination or freedom does it generate? Should it be limited to Venice, or should it spread to terra firma? These questions take us to the very meaning of carnival in the age of the internet, to what it can still tell us about "sticking together," about being together, about the desire to have fun-whether at a private party or in the midst of a crowd in public space-and about the usefulness of any entertainment whatsoever.

Journal of Festive Studies, Vol. 2, No. 1, Fall 2020, 77-104. https://doi.org/10.33823/jfs.2020.2.1.30 
J O UR N A L

OF FESTIVE

STUDIES

\section{BIBLIOGRAPHY}

Arcordia, Charles and Chantal Dickinson. "Tourism Field Studies: Experiencing the Carnival of Venice." Journal of Hospitality \& Tourism Education 25, no. 3 (2013): 146-55.

Bakhtin, Mikhail. Rabelais and His World. Bloomington: Indiana University Press, 1984. First published in 1968.

Baroja, Carlo. El Carnaval: Análisis histórico-cultural. Madrid: Taurus, 1965.

Battagia, Michele. Cicalata sulle Cacce dei Tori Veneziane. Venice: Tip. G. B. Merlo, 1844. Text was initially drafted in 1834 .

Benzoni, Gino, ed. Le metamorfosi di Venezia: Da capitale di stato a città del mondo. Florence: Olschki, 2001.

"Sfiorata l'utopia? Tra autoconsiderazione dello Stato marciano nel '500 e autoillusioni accademiche." In L'utopia di cuccagna tra '500 e '700: Il caso della Fratta nel Polesine, edited by Achille Olivieri and Massimo Rinaldi, 15-51. Rovigo: Minelliana, 2011.

"Venezia, ossia il mito modulato." In Crisi e rinnovamenti nell'autunno del Rinascimento a Venezia, edited by Vittore Branca and Carlo Ossola, 43-59. Florence: Olschki, 1991.

Bernis, François Joachim de Pierre de. Mémoires et lettres. Edited by Frédéric Masson. Paris: Plon, 1878.

Bertelli, Francesco. Il Carnevale Italiano Mascherato ove si Veggono in Figura Varie Inventione di Capritii. Venice: n.p., 1642.

Bertelli, Stefania. Il Carnevale di Venezia nel Settecento. Rome: Jouvence, 1992.

Bertrand, Aloysius, "La chanson du masque." In Gaspard de la nuit: Fantaisies à la manière de Rembrandt et de, bk. 5, edited by Aloysius Bertrand. Paris: Labitte; Angers: V. Pavie, 1842.

Bertrand, Gilles. Histoire du Carnaval de Venise, XIe-XXIe siècle. Paris: Pygmalion, 2013.

Boissevain, Jeremy, ed. Revitalizing European Rituals. London: Routledge, 1992.

Braudel, Fernand. Civilisation matérielle, économie et capitalisme: XVe-XVIIle siècle. Paris: Armand Colin, 1967. Translated by Siân Reynolds as Civilization and Capitalism, $15^{\text {th }}-18^{\text {th }}$ Century. New York: Harper \& Row, 1982-84.

Le modèle italien. Paris: Arthaud, 1989.

"L'Italia fuori d'Italia: Due secoli e tre Italie." In Storia d'Italia. Vol. 7, Dalla caduta dell'impero romano al secolo XVIII, edited by Ruggero Romano and Corrado Vivanti, 2092-2248. Turin: Einaudi, 1974.

Venise. Paris, Arthaud, 1984.

Bressanello, Alessandro. Il carnevale in età moderna: 30 anni di carnevale a Venezia 1980-2010. Venice: Studio LT2, 2010. 


\section{$J O U R N A L$}

OF FESTIVE

STUDIES
Brosses, Charles de. Lettres d'Italie. Paris: Mercure de France, 1986. First published in 1799.

Burke, Peter. "Le carnaval de Venise: Esquisse pour une histoire de longue durée." In Les jeux à la Renaissance, edited by Philippe Ariès and Jean-Claude Margolin, 55-64. Paris: J. Vrin, 1982.

Casanova, Giacomo. Histoire de ma vie. 12 vols. Wiesbaden: F. A. Brockhaus, 1960-62.

Correnti, Pino. Il carnevale di Venezia. Milan: Ecotour, 1968.

Coyer, Gabriel-François. Voyages d'Italie et de Hollande. 2 vols. Paris: Duchesne, 1775.

Crouzet-Pavan, Élisabeth. "Dynamiques de langages: Pour une relecture du système rituel vénitien (XIIIe-XVe siècle)." In Le destin des rituels: Faire corps dans l'espace urbain, ItalieFrance-Allemagne, edited by Gilles Bertrand and Ilaria Taddei, 95-115. Rome: École française de Rome, 2008.

Venise triomphante: Les horizons d'un mythe. Paris: Albin Michel, 1999. Translated by Lydia G. Cochrane as Venice Triumphant: The Horizons of a Myth. Baltimore, MD: Johns Hopkins University Press, 2002.

Eagleton, Terry. Walter Benjamin, or Towards a Revolutionary Criticism. New York: Verso Books, 2009. First published in 1981.

Elias, Norbert. The Civilizing Process. New York: Urizen Books, 1978.

Fabre, Daniel. Carnaval ou la Fête à l'envers. Paris: Gallimard, 1992.

Fermanel, Gilles, Robert Fauvel, Baudouin de Launay, and Vincent Stochove. Le voyage d'Italie et du Levant. Rouen: C. Maurry, 1670.

Ferris, Kate. Everyday Life in Fascist Venice, 1929-40. London: Palgrave Macmillan, 2012.

Fincardi, Marco. "I fasti della 'tradizione': Le cerimonie della nuova venezianità." In Vol. 2 of La Storia di Venezia: L'Ottocento e il Novecento, edited by Mario Isnenghi and Stuart J. Woolf, 1485-1522. Rome: Istituto della Enciclopedia italiana, 2002.

Fontana, Alessandro. Il vizio occulto. Ancona: Transeuropa, 1989.

"La vérité des masques." In Venise 1297-1797: La république des castors, edited by Alessandro Fontana and Georges Saro, 235-61. Saint-Cloud: ENS Editions Fontenay/Saint-Cloud, 1997.

Forrest, John. The History of Morris Dancing, 1458-1750. Toronto: University of Toronto Press, 1999.

Fournier, Laurent-Sébastien. "Traditional Festivals: From European Ethnology to Festive Studies." Journal of Festive Studies 1, no. 1 (Spring 2019): 11-26.

Fragnito, Gigliola, and Alain Tallon, eds. Hétérodoxies croisées, catholicismes pluriels entre France et Italie, XVIe-XVIle siècles. Rome: École française de Rome, 2017.

Gaignebet, Claude. Le carnaval: Essais de mythologie populaire. Paris: Payot, 1974. Text established by Marie-Claude Fromentin.

Journal of Festive Studies, Vol. 2, No. 1, Fall 2020, 77-104. https://doi.org/10.33823/jfs.2020.2.1.30 


\section{J OURNAL}

OF FESTIVE

STUDIES

Gautier, Théophile. Italia. Paris: V. Lecou, 1852.

Giron-Panel, Caroline. Musique et musiciennes à Venise: Histoire sociale des ospedali. Rome: École française de Rome, 2014.

Goldoni, Carlo. Villegiatura trilogy. Translated by Robert Cornthwaite. Lyme, NH: Smith and Kraus, 1994.

Goncourt, Edmond and Jules de Goncourt. L'Italie d'hier, notes de voyage, 1855-1856. Paris: G. Charpentier and E. Fasquelle, 1894.

Herscher, Georges, ed. Venise en fêtes. Paris: Chêne, 1992.

Hofmannstahl, Hugo von. Andreas or the United. London: J. M. Dent \& Sons, 1936. Andreas oder die Vereinigten was an unfinished novel, written between 1907 and 1927, and finally published in German in 1932.

Johnson, James H. Venice Incognito: Masks in the Serene Republic. Berkeley: University of California Press, 2017.

Limojon de Saint-Disdier, Alexandre-Toussaint. La ville et la République de Venise. Paris: Guillaume de Luyne, 1680.

Locke, Ralph P. Music and the Exotic from the Renaissance to Mozart. Cambridge: Cambridge University Press, 2015.

Longo Antonio. Memorie della vita di Antonio Longo viniziano scritte e pubblicate da lui medesimo per umilta. Venice: Antonio Curti, 1820.

MacClancy, Jeremy and Robert Parkin. "Revitalization or Continuity in European Ritual? The Case of San Bessu." The Journal of the Royal Anthropological Institute 3, no. 1 (March 1997): 61-78.

Mallé, Marie-Pascale, ed. Le monde à l'envers: Carnavals et mascarades d'Europe et de Méditerranée. Paris: Flammarion; Marseille: MuCEM, 2014.

Mariani, Filippo, Francesco Stocco, and Giorgio Crovato. La reinvenzione di Venezia: Tradizioni cittadine negli anni ruggenti. Padua: II Poligrafo, 2007.

Misson, Maximilien. Nouveau Voyage d'Italie, fait en l'année 1688, avec un mémoire contenant des avis utiles à ceux qui voudront faire le mesme voyage. La Haye: H. van Bulderen, 1691.

Molmenti, Pompeo. Storia di Venezia nella vita privata dalle origini alla caduta della Repubblica. Bergamo: Istituto italiano d'arti grafiche, 1927-29. First published in 1879.

Monnier, Philippe. Venise au XVIIIe siècle. Paris: Perrin et Cie, 1907.

Montesquieu, Mes voyages. Edited by Jean Ehrard (with the collaboration of Gilles Bertrand). Paris: Classiques Garnier; Lyon: ENS Editions, 2012.

Morgant, Louise-Marie. "Venise et ses masques: Étude de la résurgence du carnaval vénitien." PhD diss., University of Rennes 2, 1987. Lille: Atelier National de Reproduction des Thèses.

Muir, Edward. Civic Ritual in Renaissance Venice. Princeton, NJ: Princeton University Press, 1981. 
J OURNAL

OF FESTIVE

STUDIES
Muraro, Maria Teresa. "La festa a Venezia e le sue manifestazioni rappresentative: Le compagnie della Calza e le Momarie." In Storia della cultura veneta, edited by Girolamo Arnaldi and Manlio Pastore Stocchi. Vol. 3, Dal primo Quattrocento al Concilio di Trento, no. 3, 315-41. Vicenza: Neri Pozza, 1981.

Pavanello, Giuseppe and Giandomenico Romanelli, eds. Venezia nell'Ottocento: Immagini e mito. Milan: Electa, 1983.

Saint-Non, Jean-Claude Richard, Abbé de. Panopticon italiano: Un diario di viaggio ritrovato, 1759-1761. Rome: Ed. dell'elefante, 1986.

Reato, Danilo. Storia del carnevale di Venezia. Venice: Amministrazione della provincia di Venezia, Assessorato alla cultura, 1988.

Régnier, Henri de. Esquisses vénitiennes. Paris: L’Art décoratif, 1906.

L’Altana, ou la vie vénitienne. Paris: Mercure de France, 1928.

Renier, Alessandro. Venezia '800: II Carnevale. Primo '900. La Riva degli Schiavoni. I Pubblici Giardini. Venice: La Toletta, 2013.

Renier Michiel, Giustina. Origine delle feste veneziane. 5 vols. Venice: Tipografia di Alvisopoli, 1817.

Rossi, Giovanni. Costumi Veneziani, unpublished manuscript, Biblioteca Marciana, Venice. Rubenstein, Joseph. "Carnival Unmasked: Transformations of Performance in Venice." Anthropology Humanism Quarterly 15, nos. 2-3 (1990): 53-60.

Sand, George. Correspondance. Vol. 2, (1832-June 1835). Edited by Georges Lubin. Paris: Garnier frères, 1966.

Sand, Maurice. Masques et bouffons: Comédie italienne. Paris: Michel-Lévy frères, 1860.

Schnitzler, Arthur. Casanova's Homecoming. New York: Priv. print for subscribers only, 1921. Initially published in German as Casanovas Heimfahrt in 1918.

Sollers, Philippe. Dictionnaire amoureux de Venise. Paris: Plon, 2004.

La Fête à Venise. Paris: Gallimard, 1991.

Tamassia Mazzarotto, Bianca. Le feste veneziane: I giochi popolari, le cerimonie religiose e di governo. Florence: Sansoni, 1961.

Tonelli, Anna. Falce e tortello: Storia politica e sociale delle feste dell'Unità (1945-2011). RomeBari: Laterza, 2012.

Trexler, Richard. C. Public Life in Renaissance Florence. Ithaca, NY: Cornell University Press, 1991. Urban Padoan, Lina. "Feste ufficiali e trattenimenti privati." In Storia della cultura veneta, edited by Girolamo Arnaldi and Manlio Pastore Stocchi. Vol. 4, I/ Seicento, no. 1, 575-600. Vicenza: Neri Pozza, 1983.

"Il carnevale veneziano." In Storia della cultura veneta, edited by Girolamo Arnaldi and 
J O U R N L L OF FESTIVE STUDIES
Manlio Pastore Stocchi. Vol. 5, Il Settecento, no. 1, 631-46. Vicenza: Neri Pozza, 1985. La festa del giovedi grasso. Venice: Centro internazionale della grafica, 1988. Processioni e feste dogali: "Venetia est mundus." Vicenza: N. Pozza, 1998.

Zorzi, Alvise. Venezia austriaca (1798-1866). Gorizia: Libreria ed. Goriziana, 2000. First published in 1985. 


\section{$J O U R N A L$}

OF FESTIVE

STUDIES

\section{AUTHOR BIO}

Gilles Bertrand is professor of early modern history at the University of Grenoble Alpes, France, and works on Italy from a cultural history perspective. He has published books on Venetian Carnival (Histoire du carnaval de Venise, XIe-XXIe siècle, 2013 and 2017); on the relations between the Italian Peninsula and France (La France et l'Italie: Histoire de deux nations sœurs, de 1660 à nos jours, 2016, with Jean-Yves Frétigné et Alessandro Giacone); and on the seventeenth-, eighteenth-, and early nineteenth-century tradition of the Grand Tour in its material and epistemological dimensions (Le Grand Tour revisité: Le voyage des Français en Italie, milieu XVIIIe-début XIXe siècle, 2008). With Jean Ehrard he has coordinated the edition of Montesquieu's travels (Mes voyages, 2012) and with Marina Pieretti he has edited a late eighteenth-century account of a Roman marchioness's trip to northern and southern Italy (Una marchesa in viaggio per l'Italia, 2019).

\section{OPEN ACCESS}

(c) 2020 by the author. Licensee $\mathrm{H}$-Net: Humanities \& Social Sciences Online. This article is an open access article distributed under the terms and conditions of the Creative Commons Attribution-NonCommercial-NoDerivs 3.0 license (https://creativecommons.org/licenses/bync-nd/3.0/)

\section{HOW TO CITE}

Bertrand, Gilles. "Venice Carnival from the Middle Ages to the Twenty-First Century: A Political Ritual Turned 'Consumer Rite'?" Journal of Festive Studies 2, no. 1 (Fall 2020): 77-104. https:// doi.org/10.33823/jfs.2020.2.1.30

The Journal of Festive Studies (ISSN 2641-9939) is a peer-reviewed open access journal from $\mathrm{H}$-Celebration, a network of $\mathrm{H}$-Net: Humanities \& Social Sciences Online, and is the inaugural

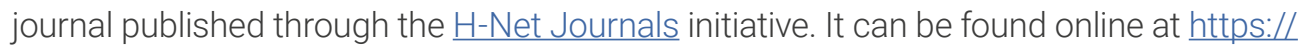
journals.h-net.org/jfs. 